\title{
Simulating the SOA formation of isoprene from partitioning and aerosol phase reactions in the presence of inorganics
}

\author{
Ross L. Beardsley and Myoseon Jang \\ Department of Environmental Engineering Sciences, University of Florida, P.O. Box 116450, Gainesville, FL 32611, USA \\ Correspondence to: Myoseon Jang (mjang@ufl.edu)
}

Received: 13 October 2015 - Published in Atmos. Chem. Phys. Discuss.: 25 November 2015

Revised: 7 April 2016 - Accepted: 8 April 2016 - Published: 17 May 2016

\begin{abstract}
The secondary organic aerosol (SOA) produced by the photooxidation of isoprene with and without inorganic seed is simulated using the Unified Partitioning Aerosol Phase Reaction (UNIPAR) model. Recent work has found the SOA formation of isoprene to be sensitive to both aerosol acidity $\left(\left[\mathrm{H}^{+}\right], \mathrm{mol} \mathrm{L}^{-1}\right)$ and aerosol liquid water content (LWC) with the presence of either leading to significant aerosol phase organic mass generation and large growth in SOA yields $\left(Y_{\text {SOA }}\right)$. Classical partitioning models alone are insufficient to predict isoprene SOA formation due to the high volatility of photooxidation products and sensitivity of their mass yields to variations in inorganic aerosol composition. UNIPAR utilizes the chemical structures provided by a near-explicit chemical mechanism to estimate the thermodynamic properties of the gas phase products, which are lumped based on their calculated vapor pressure (eight groups) and aerosol phase reactivity (six groups). UNIPAR then determines the SOA formation of each lumping group from both partitioning and aerosol phase reactions (oligomerization, acid-catalyzed reactions and organosulfate formation) assuming a single homogeneously mixed organic-inorganic phase as a function of inorganic composition and $\mathrm{VOC} / \mathrm{NO}_{x}$ (VOC - volatile organic compound). The model is validated using isoprene photooxidation experiments performed in the dual, outdoor University of Florida Atmospheric PHotochemical Outdoor Reactor (UF APHOR) chambers. UNIPAR is able to predict the experimental SOA formation of isoprene without seed, with $\mathrm{H}_{2} \mathrm{SO}_{4}$ seed gradually titrated by ammonia, and with the acidic seed generated by $\mathrm{SO}_{2}$ oxidation. Oligomeric mass is predicted to account for more than $65 \%$ of the total organic mass formed in all cases and over $85 \%$ in the presence of strongly acidic seed. The model is run to determine the sensitivity of $Y_{\mathrm{SOA}}$ to $\left[\mathrm{H}^{+}\right], \mathrm{LWC}$ and
\end{abstract}

$\mathrm{VOC} / \mathrm{NO}_{x}$, and it is determined that the SOA formation of isoprene is most strongly related to $\left[\mathrm{H}^{+}\right]$but is dynamically related to all three parameters. For $\mathrm{VOC} / \mathrm{NO}_{x}>10$, with increasing $\mathrm{NO}_{x}$ both experimental and simulated $Y_{\mathrm{SOA}}$ increase and are found to be more sensitive to $\left[\mathrm{H}^{+}\right]$and LWC. For atmospherically relevant conditions, $Y_{\mathrm{SOA}}$ is found to be more than $150 \%$ higher in partially titrated acidic seeds $\left(\mathrm{NH}_{4} \mathrm{HSO}_{4}\right)$ than in effloresced inorganics or in isoprene only.

\section{Introduction}

Volatile organic compounds (VOCs) are emitted into the atmosphere from both biogenic and anthropogenic sources. Once emitted, these compounds react with atmospheric oxidants and radicals to form semi-volatile products that may self-nucleate or partition onto preexisting particulate matter to form secondary organic aerosol (SOA). Isoprene (2methyl-1,3-butadiene) is a biogenic VOC with the largest emission of all non-methane hydrocarbons (Guenther et al., 2006), and yet it was initially thought to form insignificant amounts of SOA due to the volatility of its principal oxidation products. This conclusion was supported by early chamber investigations that found isoprene only forms SOA at concentrations much higher than ambient conditions (Pandis et al., 1991; R. M. Kamens et al., 1982). However, recent chamber (Edney et al., 2005; Kroll et al., 2005, 2006; Limbeck et al., 2003) and field studies (Claeys et al., 2004; Edney et al., 2005) found that the large emission rate of isoprene makes the contribution to global SOA formation significant even at low yields, and it is estimated that isoprene is the largest single source of global organic aerosol (Henze 
and Seinfeld, 2006). The proposal of new SOA formation mechanisms, primarily the classical equilibrium partitioning theory by Pankow (1994) and the discovery of aerosol phase oligomerization reactions in the presence of inorganic acids (Jang et al., 2002, 2003), led to the reexamination of the SOA formation potential of isoprene. More recent studies have found the SOA yield of isoprene and its oxidation products to be highly sensitive to aerosol acidity $\left(\left[\mathrm{H}^{+}\right], \mathrm{mol} \mathrm{L}^{-1}\right.$ aerosol) (Jang et al., 2002; Kuwata et al., 2015; Limbeck et al., 2003; Surratt et al., 2010) and aerosol liquid water content (LWC).

The tendency of isoprene photooxidation products to engage in aerosol phase oligomerization reactions is primarily due to the reactivity of its secondary products. The presence of two double bonds makes isoprene highly reactive and allows for rapid $\mathrm{OH}$-initiated oxidation in the atmosphere. The distribution of isoprene photooxidation products and the resultant SOA yields are dependent on $\mathrm{NO}_{x}$ concentrations and atmospheric aging. When $\mathrm{NO}_{x}$ concentrations are low, $\mathrm{RO}_{2}$ radicals react with $\mathrm{HO}_{2}$ radicals to form hydroxyperoxides $(\mathrm{ROOH})$ at high yield. Then, $\mathrm{ROOH}$ further react with $\mathrm{OH}$ radicals to form dihydroxyepoxides (IEPOX) (Paulot et al., 2009). IEPOX has been found to undergo rapid reactive uptake onto wet ammonium sulfate (AS) inorganic aerosol and acidic inorganic seeds at all relative humidities (RHs) leading to the formation of tetrols, organosulfates (OS) and other low-volatility oligomers. In the presence of high $\mathrm{NO}_{x}$, SOA formation will depend on the ratio of $\mathrm{NO}_{2}$ to $\mathrm{NO}$ with isoprene $\mathrm{SOA}$ yields being be lower at low $\mathrm{NO}_{2} / \mathrm{NO}$ due to $\mathrm{RO}_{2}$ reacting with $\mathrm{NO}$ to produce more volatile products (Kroll et al., 2006; Surratt et al., 2010).

In order to quantify and understand the impact of SOA on climate and human health, the prediction of SOA formation of isoprene is essential. SOA models have been developed and utilized to predict the SOA formation of various VOC systems. The two-product model was developed based on classical partitioning theory (Pankow, 1994) and represents SOA formation through the use of two or more representative secondary products of varying vapor pressure (Odum et al., 1996). By fitting the stoichiometric and partitioning coefficients of each representative semi-volatile organic compound (SVOC) to experimental data, the SOA yield of a VOC is predicted as a function of the absorbing organic mass (OM) concentration without considering the numerous gas phase products. The simple and efficient handling of SOA mass formation from partitioning by the two-product model led to its widespread use in regional and global models. Nevertheless, the two-product model and its predecessors are limited in their ability to predict SOA formation from aerosol phase reactions in the presence of inorganic aerosol due to the loss of individual product structures, which determine reactivity in the aerosol phase, and due to the need to fit new parameters for variations in atmospheric conditions. Many regional models have already incorporated different sets of parameters for each VOC under high- and low- $\mathrm{NO}_{x}$ regimes but cannot handle the variations seen in ambient aerosol LWC and $\left[\mathrm{H}^{+}\right]$that enhance SOA formation via aerosol phase reactions (Carlton et al., 2009).

More recent studies have modeled aqueous phase SOA production using empirically determined uptake coefficients or effective Henry's constants (when available) to estimate the reactive uptake of major isoprene products, such as IEPOX and glyoxal, in the inorganic aqueous phase (Marais et al., 2016; McNeill et al., 2012; Pye et al., 2013; Woo and McNeill, 2015). For example, McNeill et al. (2012) developed the GAMMA (Gas-Aerosol Model for Mechanism Analysis) to predict the aqueous SOA production of isoprene in the presence of deliquesced ammonium sulfate. Pye et al. (2013) modified the regional Community Multi-scale Air Quality model to include the heterogeneous uptake of IEPOX and methacrylic acid epoxide. While these models greatly improve the predictions of isoprene SOA formation over classical partitioning models, SOA formation of these known products via aqueous phase reactions is not fully representative of total isoprene SOA formation. Edney et al. (2005) measured the composition of isoprene SOA in the presence of acidic inorganic seed, and methylglyceric acid and 2-methyltetrols, which are tracer species for aqueous phase reactions, made up only $6 \%$ of the total SOA mass, with the majority of the products being unidentified. Furthermore, highly oxidized oligomers comprise the majority of isoprene SOA even in the absence of an inorganic aqueous phase (Nguyen et al., 2010, 2011; Surratt et al., 2006) due to aerosol phase reactions in organic-only aerosol. The photooxidation of isoprene produces a large number of highly reactive products (epoxides, carbonyls) that will react even in the absence of an inorganic aqueous phase to produce the large fraction of high molecular weight (MW) species. Therefore, while the high contribution of the aqueous phase products of IEPOX and similar compounds makes them ideal tracers, they are not fully representative of isoprene SOA as is demonstrated by the large number of high-MW products and lack of mass closure in isoprene composition studies even in the absence of an inorganic aqueous phase.

In this study, the Unified Partitioning-Aerosol Phase Reaction (UNIPAR) model, which was previously developed and applied to aromatic VOCs (Im et al., 2014), was updated and expanded to model the SOA formation of isoprene in the presence of low $\mathrm{VOC} / \mathrm{NO}_{x}$ (due to the high sensitivity to $\left[\mathrm{H}^{+}\right]$in the low- $\mathrm{NO}_{x}$ regime) and aerosol acidity using natural sunlight. UNIPAR predicts SOA formation from gasparticle partitioning and oligomerization reactions in both organic-only aerosol and the inorganic aqueous phase, using a lumping structure that was developed to be representative of the thermodynamic properties and chemical reactivity of oxidized products in the aerosol phase. The model was validated using outdoor chamber data from isoprene photooxidation experiments with and without acidic inorganic seeds. 
Table 1. Experimental conditions and resulting SOA data of the isoprene photooxidation experiments performed with and without inorganic acidic seed in the dual, outdoor UF APHOR chambers.

\begin{tabular}{llrrrrrrr}
\hline Exp. & Date & $\begin{array}{r}\mathrm{RH} \\
(\%)\end{array}$ & $\begin{array}{r}\mathrm{Temp} \\
(\mathrm{K})\end{array}$ & $\begin{array}{r}{[\mathrm{ISO}]_{0}} \\
(\mathrm{ppb})\end{array}$ & $\begin{array}{r}{\left[\mathrm{NO}_{x}\right]_{0}} \\
(\mathrm{ppb})\end{array}$ & $\begin{array}{r}\mathrm{VOC}_{\left(\mathrm{NO}_{x}\right.} \\
\left(\mathrm{ppbC} \mathrm{ppb}^{-1}\right)\end{array}$ & $\begin{array}{r}{\left[\mathrm{H}_{2} \mathrm{SO}_{4}\right]} \\
\left(\mu \mathrm{g} \mathrm{m}^{-3}\right)\end{array}$ & $\begin{array}{r}Y_{\mathrm{SOA}}^{\mathrm{a}} \\
(\%)\end{array}$ \\
\hline ISO1 & 27 Jan 2015 & $27-66$ & $279-298$ & 839 & 241 & 17.4 & 0 & 2.5 \\
SA1 & 27 Jan 2015 & $20-54$ & $279-299$ & 850 & 253 & 16.8 & 53 & 8.5 \\
ISO2 & 14 Dec 2014 & $19-49$ & $282-303$ & 852 & 131 & 32.7 & 0 & 0.7 \\
SA2 & 14 Dec 2014 & $14-40$ & $284-305$ & 857 & 130 & 32.5 & 40 & 4.8 \\
SO2 & 18 Jan 2014 & $48-91$ & $273-292$ & 627 & 91 & 34.6 & $26^{\mathrm{b}}$ & 3.0 \\
\hline
\end{tabular}

${ }^{\mathrm{a}} \mathrm{SOA}$ yield $\left(Y_{\mathrm{SOA}}=\Delta \mathrm{OM} / \Delta \mathrm{Iso}\right)$ is calculated at the point of maximum organic mass $(\mathrm{OM}) .{ }^{\mathrm{b}}$ In experiment $\mathrm{SO}_{2}, \mathrm{SO}_{2}(\mathrm{~g})$ was injected into the chamber to generate acidic seeds instead of directly injecting $\mathrm{H}_{2} \mathrm{SO}_{4}(\mathrm{aq})$.

\section{Experimental methods}

Isoprene SOA photooxidation experiments were performed in the University of Florida Atmospheric PHotochemical Outdoor Reactor (UF-APHOR) chambers over the period of 1 day. The dual $52 \mathrm{~m}^{3}$ Teflon film chambers were operated simultaneously to allow for the investigation of two different experimental conditions under the same ambient, diurnal profiles of sunlight, $\mathrm{RH}$ and $T$. The chamber air was cleaned using air purifiers (GC Series, IQAir) for $48 \mathrm{~h}$ prior to each experiment. In the experiments in which inorganic seeds were used, a $0.01 \mathrm{M}$ aqueous solution of $\mathrm{H}_{2} \mathrm{SO}_{4}$ (SA) was atomized using a nebulizer (LC STAR, Pari Respiratory Equipment) with clean air flow. Next, the desired volume of NO (2\% in $\mathrm{N}_{2}$, Airgas) was injected into the chamber and finally, isoprene (99\%, Sigma Aldrich) and $\mathrm{CCl}_{4}(>99.9 \%$, Sigma Aldrich) were injected using a glass manifold with clean air. $\mathrm{CCl}_{4}$ was used as a tracer for dilution. All chemical species were injected early enough to allow for stabilization and measurement before reactions began with sunrise. The experimental conditions for each of the chamber runs is shown in Table 1.

To allow for gas and aerosol phase characterization, chamber air is pumped through a number of sampling lines into the lab that is located directly below the roof. Gas phase concentrations of $\mathrm{NO}_{x}, \mathrm{O}_{3}$ and $\mathrm{SO}_{2}$ were measured using a Teledyne Model 200E Chemiluminescence NO-NO $x$ Analyzer, Model 400E Photometric $\mathrm{O}_{3}$ Analyzer and Model 102E Fluorescence TRS Analyzer, respectively. An HP 5890 Gas Chromatography-Flame Ionization Detector was employed with an oven temperature of $40^{\circ} \mathrm{C}$ to measure isoprene and $\mathrm{CCl}_{4}$ concentrations. A semicontinuous OC/EC aerosol analyzer (Sunset Laboratory, Model 4) following the NIOSH 5040 method was utilized to measure organic carbon (OC) mass concentration $\left(\mu \mathrm{gC} \mathrm{m}{ }^{-3}\right)$ and then converted to $\mathrm{OM}$ using an OM / OC ratio of 2.2 (Aiken et al., 2008; Kleindienst et al., 2007). Particle number and volume concentrations were measured with a scanning mobility particle sizer coupled with a condensation nuclei counter (TSI, Model 3025A and Model 3022). Particle wall loss was corrected using sizedependent first-order rate constants determined by a chamber characterization with inorganic seed. A particle-into-liquid sampler (Applikon, ADI 2081) coupled to ion chromatography (Metrohm, 761Compact IC) (PILS-IC) was used to quantify aerosol phase inorganic ions.

The colorimetry integrated with reflectance UV-visible spectrometer (C-RUV) technique (Jang et al., 2008; Li et al., 2015; $\mathrm{Li}$ and Jang, 2012) was used to measure $\left[\mathrm{H}^{+}\right]$ (mol L ${ }^{-1}$ aerosol) in experiment SA2. The C-RUV technique utilizes a dyed filter to collect aerosol and act as an indicator for particle acidity. The change in color is measured using a UV-visible spectrometer in absorbance mode and allows for determination of $\left[\mathrm{H}^{+}\right]$using a calibration curve. Then the amount of sulfate $\left(C_{\mathrm{SO}_{4}^{2-}}, \mu \mathrm{mol} \mathrm{m}{ }^{-3}\right)$ that forms organosulfates (OS) $\left(C_{\mathrm{SO}_{4}^{2-}}^{\mathrm{OS}}\right)$ is then estimated by comparing the actual particle $\left[\mathrm{H}^{+}\right]$, as measured by the C-RUV technique, to the $\left[\mathrm{H}^{+}\right]$predicted by the inorganic thermodynamic model, EAIM II (Extended Aerosol Inorganics Model; Clegg et al., 1998) using the inorganic composition from PILS-IC. OS are reversible in the high-temperature water droplets of the PILS system, and so the measured $C_{\mathrm{SO}_{4}^{2-}}$ is the total sulfate including OS. Therefore, by reducing the $C_{\mathrm{SO}_{4}^{2-}}$ input into E-AIM II until the predicted $\left[\mathrm{H}^{+}\right]$matches the actual value measured by the C-RUV method, the amount of $\mathrm{C}_{\mathrm{SO}_{4}^{2-}}^{\mathrm{OS}}$ that led to a reduction in acidity can be estimated (Li et al., 2015). The esterification of sulfuric acid produces both alkyl bisulfates $\left(\mathrm{ROSO}_{3} \mathrm{H}\right)$, which are strong acids, and dialkylsulfates $\left(\mathrm{ROSO}_{2} \mathrm{OR}\right)$, which are neutral. Therefore, only dialkylsulfates lead to a significant reduction in $\left[\mathrm{H}^{+}\right]$. For this reason, the OS measured using the C-RUV method are only dialkylsulfates.

A more detailed explanation of the use of the C-RUV technique to estimate OS in SOA can be found in $\mathrm{Li}$ et al. (2015). A more complete description of the experimental design and chamber operation can be found in Im et al. (2014).

\section{Model description}

UNIPAR simulates the SOA formation of the VOC- $\mathrm{NO}_{x}$ photooxidation products from both partitioning and aerosol 
phase reactions. The photooxidation of the VOC is predicted explicitly offline, and products are lumped using their volatility and reactivity in aerosol phase reactions (Sect. 3.1). SOA formation is then predicted for the lumped species dynamically as a function of the inorganic aerosol composition $\left(\left[\mathrm{H}^{+}\right], \mathrm{LWC}\right)$. The inputs of the model are the consumption of isoprene $(\triangle \mathrm{ISO}), \mathrm{VOC} / \mathrm{NO}_{x}$, the change in aerosol phase sulfate $\left(\Delta C_{\mathrm{SO}_{4}^{2-}}, \mu \mathrm{mol} \mathrm{m}{ }^{-3}\right)$ and ammonium ions $\left(\Delta C_{\mathrm{NH}_{4}^{+}}\right.$, $\left.\mu \mathrm{mol} \mathrm{m}{ }^{-3}\right)$, and $T$ and $\mathrm{RH}$ at each time step $(\Delta t=3 \mathrm{~min})$.

The overall model schematic is shown in Fig. 1. In order to account for the effects of inorganic aerosol, isoprene SOA formation is approached in two ways: SOA formation in the presence of deliquesced inorganic seed $\left(C_{\mathrm{SO}_{4}^{2-}}>0\right.$ and $\mathrm{RH}>\mathrm{ERH})$ and either isoprene only $\left(C_{\mathrm{SO}_{4}^{2-}}=0\right)$ or effloresced inorganic seed $\left(C_{\mathrm{SO}_{4}^{2-}}>0\right.$ and $\left.\mathrm{RH}<\mathrm{ERH}\right)$ (Sects. 3.2 and 3.3). First, the total mass originating from $\triangle \mathrm{VOC}$ in each $\Delta t$ is split among the lumping groups $\left(i_{m, n}\right)$ and combined with the remaining gas phase concentrations from previous steps to get the total gas phase concentration of each $i_{m, n}$ $\left(C_{\mathrm{g}, i}, \mu \mathrm{g} \mathrm{m}^{-3}\right)$ (Sect. 3.1). Then the concentrations in the aerosol phase $\left(C_{\text {mix }, i}, \mu \mathrm{g} \mathrm{m}^{-3}\right)$ are calculated based on the aerosol phase state. Using the estimated $C_{\mathrm{mix}, i}$ and inorganic aerosol composition, the OM formation from aerosol phase reactions $\left(\mathrm{OM}_{\mathrm{AR}}, \mu \mathrm{g} \mathrm{m}^{-3}\right)$ is calculated (Sect. 3.3.1). $\mathrm{OM}_{\mathrm{AR}}$ includes SOA formation from organic-only oligomerization reactions, aqueous phase reactions, acid-catalyzed reactions and $\mathrm{OS}$ formation (Sect. 3.3.2). $\mathrm{OM}_{\mathrm{AR}}$ is assumed to be nonvolatile and irreversible. Finally, the OM from partitioning $\left(\mathrm{OM}_{\mathrm{P}}, \mu \mathrm{g} \mathrm{m}^{-3}\right)$ is predicted using the module developed by Schell et al. (2001) modified to account for the assumed nonvolatility and irreversibility of $\mathrm{OM}_{\mathrm{AR}}$ (Sect. 3.3.3).

\subsection{Gas phase photooxidation and lumping structure}

The photooxidation of isoprene was simulated using the Master Chemical Mechanism (MCM) v3.2 (Saunders et al., 1997, 2003) within the Morpho kinetic solver (H. E. Jeffries et al., 1998). Simulations were performed under varying VOC $/ \mathrm{NO}_{x}$ ratios $\left(\mathrm{ppbC} \mathrm{ppb}^{-1}\right)$ using the sunlight, temperature and RH data from 23 April 2014. All of the simulations began with $\mathrm{NO}$ and started with sunrise. The sunlight, RH and temperature profiles used as well as an example gas phase simulation with corresponding experimental data (Sect. S1) can be seen in the Supplement.

The predicted photooxidation products are then lumped in UNIPAR using vapor pressure ( $m$, eight bins) and reactivity ( $n$, six bins). The lumping structure is shown in Fig. S3 in the Supplement including the structure of the product which contributes most to each lumping group. The subcooled liquid vapor pressure of each product $\left(p_{\mathrm{L}, i}^{o}\right)$ is estimated using a group contribution method (Joback and Reid, 1987; Stein and Brown, 1994; Zhao et al., 1999), which is explained in detail in Im et al. (2014). The reactivity of each product is estimated based on the number of reactive func-

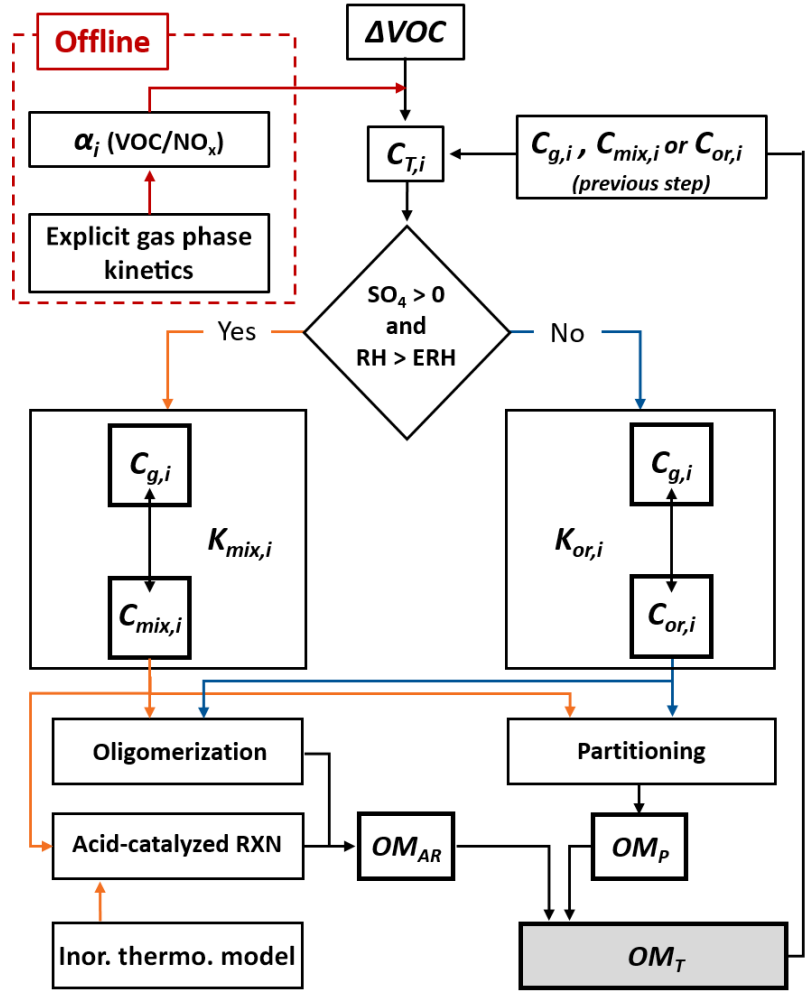

Figure 1. The overall schematic of the model applied to simulate isoprene SOA within UNIPAR. $C_{\mathrm{T}, i}$ is the total concentration of each lumping species, $i$, and $C_{\mathrm{g}, i}, C_{\mathrm{mix}, i}$ and $C_{\mathrm{or}, i}$ are the concentrations of each $i$ within the gas, single homogenously mixed (SHMP) aerosol and organic-only aerosol, respectively. $\triangle \mathrm{VOC}$ is the consumption of the volatile organic compound of interest in each time step. $\alpha_{i}$ is the stoichiometric mass ratio of each $i$, which is calculated offline as a function of VOC / $\mathrm{NO}_{x}$ based on explicit gas phase simulations and is used to distribute the total $\triangle$ VOC between each $i . K_{\mathrm{mix}, i}$ and $K_{\mathrm{or}, i}$ are the equilibrium partitioning coefficients for the SHMP and organic-only aerosol, respectively. $\mathrm{OM}_{\mathrm{T}}, \mathrm{OM}_{\mathrm{P}}$ and $\mathrm{OM}_{\mathrm{AR}}$ are the total organic mass and the organic mass from aerosol phase reactions and partitioning, respectively.

tional groups. The reactivity bins used in UNIPAR are very fast (VF, $\alpha$-hydroxybicarbonyls and tricarbonyls), fast (F, 2 epoxides or aldehydes,), medium (M, 1 epoxide or aldehyde), slow (S, ketones), partitioning only (P) and organosulfate precursors $\left(\mathrm{OS}_{\mathrm{P}}, 3\right.$ or more alcohols). The reactivity bins were developed based on previous work in which the measured gas-particle partitioning coefficients $\left(K_{\mathrm{p}}\right)$ of toluene and $\alpha$-pinene SOA products were found to deviate from the theoretical value due to higher than expected particle concentrations. The degree of deviation was found to depend on the functionalization of the SOA product (Jang et al., 2002; Jang and Kamens, 2001). The experimental $\log \left(K_{\mathrm{p}}\right)$ of ketones ( $\mathrm{S}$ reactivity bin) were found to be only slightly higher than the theoretical value, while the experimental $\log \left(K_{\mathrm{p}}\right)$ of conjugated aldehydes ( $\mathrm{M}$ reactivity bin) and the products 
associated with $\mathrm{F}$ and VF reactivity bins were found to be 10-40 times higher and 2 to 3 orders higher, respectively.

In order to account for their unique reactivity, glyoxal was allocated to group $6 \mathrm{~F}$ instead of $8 \mathrm{~F}$ and methylglyoxal was moved from $8 \mathrm{M}$ to $6 \mathrm{M}$ based on their apparent Henry's constant (Ip et al., 2009). In addition to these reactivity bins, isoprene required the designation of a medium-reactivity, multialcohol $\left(\mathrm{M}-\mathrm{OS}_{\mathrm{P}}\right)$ bin due to the large number of secondary products which contain both three or more alcohols and reactive functional groups (epoxide or aldehyde). Tetrol precursors (IEPOX), which are produced at high concentrations in the gas phase under low $\mathrm{VOC} / \mathrm{NO}_{x}$, were also given a separate reactivity bin in order to more easily quantify the SOA formation of these products predicted by the model. The concentrations of each lumping group were set at the peak $\mathrm{HO}_{2}$ / NO ratio, which generally corresponds with the time of the majority of SOA formation and represents a shift from less oxidized to more oxidized products. The corresponding stoichiometric mass coefficients $\left(\alpha_{i}\right)$ of each $i_{m, n}$ were then fit to the initial $\mathrm{VOC} / \mathrm{NO}_{x}$ ratio. At higher $\mathrm{NO}$, it takes longer to reach the peak $\mathrm{HO}_{2} / \mathrm{NO}$ ratio and SOA formation is also slower. Figure 2 shows the filled lumping structure at $\mathrm{VOC} / \mathrm{NO}_{x}$ of 25 , illustrating the high volatility and reactivity of the majority of isoprene products.

\subsection{Aerosol composition and phase state}

Tropospheric aerosols have been shown to be primarily composed of organic compounds and inorganic sulfate partially or wholly titrated with ammonia (Bertram et al., 2011; Murphy et al., 2006). Under ambient diurnal patterns of $\mathrm{RH}$, these aerosols may effloresce and deliquesce and can be liquid-liquid phase separated (LLPS) or form a single homogeneously mixed phase (SHMP) influencing the amount and composition of SOA that are produced. While dry, effloresced inorganic salts simply act as a seed for organic coating by SOA, deliquesced seeds contain liquid water into which reactive, soluble compounds can dissolve and further react producing low-volatility SOA (Hennigan et al., 2008; Lim et al., 2010; Volkamer et al., 2007). Furthermore, the type of SOA products will determine the phase state of wet aerosol. In LLPS aerosol, hydrophobic SVOC will partition primarily into the organic liquid phase, while a significant fraction of hydrophilic SVOC may dissolve into the salted liquid phase. The RH at which these transitions occur depends on the concentration and composition of the inorganic and organic components of the aerosol.

Bertram et al. (2011) semiempirically predicted the efflorescence $\mathrm{RH}(\mathrm{ERH})$, deliquescence $\mathrm{RH}(\mathrm{DRH})$ and the $\mathrm{RH}$ of LLPS (SRH) by fitting experimental data of a number of oxygenated organic-AS systems to the oxygen-to-carbon atomic ratio $(\mathrm{O}: \mathrm{C})$ and to the organic-to-sulfur mass ratio (org: sulf) of the bulk aerosol. UNIPAR utilizes these parameterizations to predict ERH and DRH at each time step $(t=j)$ using modeled $\mathrm{O}: \mathrm{C}$ and org : sulf from the previous

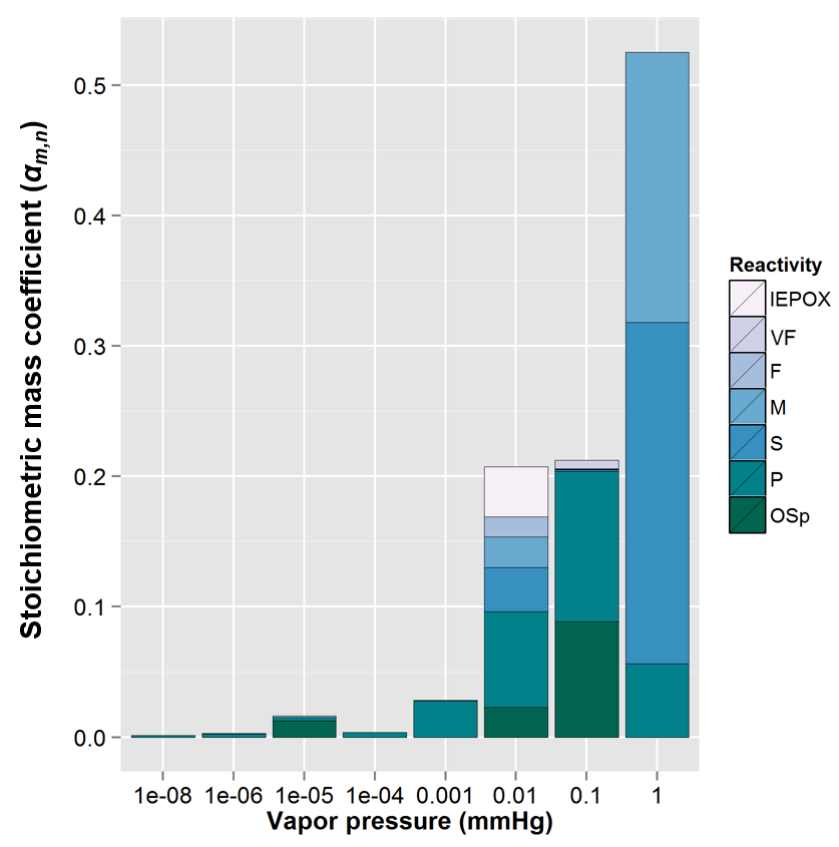

Figure 2. The stoichiometric mass coefficients $\left(\alpha_{i}\right)$ of each lumping group at a $\mathrm{VOC} / \mathrm{NO}_{x}\left(\mathrm{ppbC} \mathrm{ppb}^{-1}\right)$ of 25 . The photooxidation products predicted by an explicit gas phase chemical mechanism are lumped as a function of vapor pressure ( $x$ axis, eight bins) and aerosol phase reactivity ( $y$ axis, six bins). The aerosol phase reactivity bins are very fast (VF, $\alpha$-hydroxybicarbonyls and tricarbonyls), fast (F, 2 epoxides or aldehydes,), medium (M, 1 epoxide or aldehyde), slow (S, ketones), partitioning only (P), organosulfate precursors $\left(\mathrm{OS}_{\mathrm{P}}, 3\right.$ or more alcohols) and IEPOX products, which were lumped separately to more easily quantify their contribution.

time step $(t=j-1)$. In regard to phase state, UNIPAR is run assuming an SHMP for all of the isoprene simulations due to literature $\mathrm{O}: \mathrm{C}$ values of isoprene ranging from 0.69 to 0.88 (Bertram et al., 2011; Chen et al., 2011; Kuwata et al., 2013), which corresponds to an SRH of zero.

The interaction of organics and inorganics in SHMP SOA may alter the dissociation of inorganic acids and the resulting $\left[\mathrm{H}^{+}\right]$. In order to estimate the impact of organics on $\left[\mathrm{H}^{+}\right]$ in SHMP isoprene SOA, the percent dissociation of $\mathrm{H}_{2} \mathrm{SO}_{4}$ was determined using Aerosol Inorganic-Organic Mixtures Functional groups Activity Coefficients (AIOMFAC) model in the presence of varying amounts of tetrol and hexane, which represent polar and nonpolar organic species, under controlled RH. The change in percent dissociation was less than $15 \%$ when compared to inorganic-only aerosol at the same RH (details in the Supplement, Sect. S2). Based on these results, it was assumed that presence of organics in isoprene SHMP SOA does not significantly influence the $\left[\mathrm{H}^{+}\right]$ from inorganic acids. Therefore, $\left[\mathrm{H}^{+}\right]$is estimated for each time step by E-AIM II (Clegg et al., 1998) corrected for the ammonia-rich condition ( $\mathrm{Li}$ and Jang, 2012) as a function of inorganic composition measured by PILS-IC $\left(C_{\mathrm{SO}_{4}^{2-}}, C_{\mathrm{NH}_{4}^{+}}\right)$ 
and $\mathrm{RH}$. Then, $\left[\mathrm{H}^{+}\right]$is diluted using the ratio of the inorganic volume to the total aerosol volume. The inorganic associated LWC is also calculated using E-AIM II. The LWC of isoprene SOA is estimated in AIOMFAC using the hygroscopic growth factor of a representative isoprene SOA: $20 \%$ sucrose by mass (Hodas et al., 2015) as a surrogate for tetrol and $80 \%$ isoprene-derived oligomers (Nguyen et al., 2011). The estimated growth factor is approximately $30 \%$ of that of AS and so, in the model, the LWC of isoprene is estimated to be 0.3 of the LWC of AS without an ERH. $\left[\mathrm{H}^{+}\right]$is used to describe particle acidity and has units of $\mathrm{mol} \mathrm{H}^{+} \mathrm{L}^{-1}$ of aerosol. Therefore, $\left[\mathrm{H}^{+}\right]$will change with variation in inorganic composition, LWC and total aerosol mass (SOA). The particle $\mathrm{pH}$ is simply the negative $\log$ of $\left[\mathrm{H}^{+}\right]$.

\subsection{SOA formation}

In simulating the total $\mathrm{OM}\left(\mathrm{OM}_{\mathrm{T}}\right)$ from isoprene photooxidation, UNIPAR predicts the SOA formation for each $i_{m, n}$ from both partitioning $\left(\mathrm{OM}_{\mathrm{P}, i}\right)$ and aerosol phase reactions $\left(\mathrm{OM}_{\mathrm{AR}, i}\right)$. In the previous applications of UNIPAR for aromatic VOC (Im et al., 2014), SOA formation was modeled under the assumption of LLPS aerosol because aromatic SOA is relatively nonpolar, and thus aerosol phase concentrations of $i_{m, n}$ were calculated by means of a mass balance between the concentrations in the gas phase, the inorganic aerosol phase and the organic aerosol phase. In modeling isoprene SOA formation in the presence of an SHMP aerosol, the total concentration $\left(\mu \mathrm{g} \mathrm{m}^{-3}\right.$ of air) of each lumping species $\left(C_{\mathrm{T}, i}\right)$ was split solely between $C_{\mathrm{g}, i}$ and $C_{\mathrm{mix}, i}$ by a single gas-particle partitioning coefficient, $K_{\text {mix }, i}\left(\mathrm{~m}^{3} \mu \mathrm{g}^{-1}\right)$ :

$C_{\mathrm{T}, i}=C_{\mathrm{g}, i}+C_{\mathrm{mix}, i}$,

$K_{\mathrm{mix}, i}=\frac{C_{\mathrm{mix}, i}}{C_{\mathrm{g}, i} M_{\mathrm{mix}}}$,

where $M_{\text {mix }}$ is the total suspended matter and is the sum of the inorganic mass $\left(M_{\mathrm{in}}\right)$ and $\mathrm{OM}_{\mathrm{T}}$. The calculation of $K_{\text {mix }, i}$ follows the gas-particle absorption model (Pankow, 1994).

$K_{\text {mix }, i}=\frac{7.501 R T}{10^{9} \mathrm{MW}_{\text {mix }} \gamma_{\text {mix }, i} p_{\mathrm{L}, i}^{o}}$,

where $R$ is the gas constant $\left(8.314 \mathrm{~J} \mathrm{~K}^{-1} \mathrm{~mol}^{-1}\right), T$ is the temperature $(\mathrm{K}), \mathrm{MW}_{\text {mix }}$ is the average molecular weight $\left(\mathrm{g} \mathrm{mol}^{-1}\right)$ of the SHMP aerosol, $\gamma_{\text {mix }, i}$ is the activity coefficient of the lumping species in the SHMP aerosol and $p_{\mathrm{L}, i}^{o}$ is the sub-cooled liquid vapor pressure $(\mathrm{mm} \mathrm{Hg})$ of $i_{m, n} \cdot \gamma_{\text {mix }, i}$ accounts for the nonideality in the SHMP aerosol and allows for a more realistic representation of the differences in solubility in the aerosol phase. $\gamma_{\text {mix }, i}$ will vary between partitioning species due to differences in polarity and molar volume $\left(V_{\mathrm{mol}, i}\right)$ and also over time due to changes in LWC and aerosol composition.
In order to handle the range of possible $\gamma_{\text {mix }, i}$ in SHMP isoprene SOA, the AIOMFAC model was run using the highest-concentration product of each $i_{m, n}$ (Fig. S3) in the presence of a mixed isoprene SOA/AS aerosol. The representative isoprene SOA composition was chosen based on the results of Nguyen et al. (2011). The bulk organic-to-sulfur mass ratio (org: sulf), concentration of $i_{m, n}$ and the RH were varied to cover the range of experimental values, and the resulting $\gamma_{\text {mix }, i}$ were fit to the bulk aerosol org: sulf, $\ln (\mathrm{RH})$, and the $V_{\mathrm{mol}, i}$ and $\mathrm{O}: \mathrm{C}_{i}$ of each $i_{m, n}$ using a polynomial equation. The resulting parameterizations are shown in the Supplement along with the predicted $\gamma_{\text {mix }, i}$ plotted against $\gamma_{\text {mix }, i}$ from AIOMFAC (Sect. S4). In the absence of inorganic aerosol $\left(C_{\mathrm{SO}_{4}^{2-}}=0\right)$ or in the presence of dry inorganic aerosol, partitioning is assumed to be ideal with an organiconly partitioning coefficient $\left(K_{\mathrm{or}, i}\right)$ calculated using $\gamma_{\mathrm{mix}, i}$ of 1 (Jang and Kamens, 1998) (Fig. 1).

\subsubsection{OM from aerosol phase reactions $\left(\mathrm{OM}_{\mathrm{AR}}\right)$}

Once $C_{\mathrm{mix}, i}\left(\mu \mathrm{g} \mathrm{m}^{-3}\right)$ is determined for each $\Delta t$, the $\mathrm{OM}_{\mathrm{AR}}$ formation of $i_{m, n}$ is estimated in UNIPAR assuming a second-order self-dimerization reaction as is shown in Eq. (4):

$\frac{\mathrm{d} C_{\mathrm{mix}, i}^{\prime}}{\mathrm{d} t}=-k_{\mathrm{AR}, i} C_{\mathrm{mix}, i}^{\prime}$,

where $C_{\text {mix }, i}^{\prime}$ is the aerosol phase concentration of $i_{m, n}$ in mol L ${ }^{-1}$ of aerosol and $k_{\mathrm{AR}, i}\left(\mathrm{~L} \mathrm{~mol}^{-1} \mathrm{~s}^{-1}\right)$ is the aerosol phase reaction rate of each $i_{m, n} . k_{\mathrm{AR}, i}$ (Eq. 5) is calculated each time step using the semiempirical model developed by Jang et al. (2005) as a function of the reactivity, $R(\mathrm{VF}, \mathrm{F}, \mathrm{M}$, $\mathrm{S}$; Sect. 3.1), and $\mathrm{pK}_{\mathrm{BH}^{+}}$of $i_{m, n}$ in the aerosol phase, $\left[\mathrm{H}^{+}\right]$ and LWC (activity of water, $a_{\mathrm{w}}$ ) from the inorganic thermodynamic model (Sect. 3.2), and the excess acidity, $X$ (Im et al., 2014; Jang et al., 2006).

$k_{\mathrm{AR}, i}=10^{\left(0.0005 \cdot \mathrm{pK}_{\mathrm{BH}^{+}}+y \cdot X+1.3 \cdot R+\log \left(a_{\mathrm{w}}\right)+\log \left(\left[\mathrm{H}^{+}\right]\right)-5.5\right)}$

All of the coefficients of Eq. (5) were fit using the flow reactor experimental sets for aerosol growth of model organic compounds (various aldehydes) on acidic aerosol $\left(\mathrm{SO}_{4}^{2-}-\right.$ $\mathrm{NH}_{4}^{+}-\mathrm{H}_{2} \mathrm{O}$ system) within the LLPS module and tested for LLPS aerosol (toluene SOA and 1,3,5-trimethylbenzene SOA) by Im et al. (2014), except for the factor $y$ for $X$. In the presence of deliquesced inorganics, $k_{\mathrm{AR}, i}$ is a function of $X$, which represents the effect of an acidic inorganic medium on the reaction of the protonated organics that act as an intermediate for acid-catalyzed reactions. For LLPS aerosol, the protonated organic compounds are in highly concentrated inorganic liquid with high $X$. The mixture of organic and inorganic species in SHMP aerosol will lead to a modification of $X$ and thus the reaction rate of protonated organics. To account for this change in isoprene SOA, $y$ was determined to be 0.49 by fitting the $\mathrm{OM}_{\mathrm{T}}$ of experimental set SA1 (Table 1). 
In the absence of deliquesced inorganic species, the terms associated with the inorganic aqueous phase $\left(\left[\mathrm{H}^{+}\right]\right.$and $\left.X\right)$ approach zero, making $k_{\mathrm{AR}, i}$ primarily a function of the reactivity $(R)$ of $i_{m, n}$, allowing for the prediction of oligomerization reactions in the organic-only aerosol.

Then by assuming that $\mathrm{OM}_{\mathrm{AR}}$ is nonvolatile and irreversible, $\Delta \mathrm{OM}_{\mathrm{AR}, i}$ can be calculated as the reduction in $C_{\mathrm{T}, i}$ for each time step. The full derivation of the equations used to predict $\mathrm{OM}_{\mathrm{AR}}$ is shown in the Supplement (Sect. S3).

\subsubsection{OS formation}

Sulfuric acid produced from the photooxidation of $\mathrm{SO}_{2}$ influences aerosol phase state and hygroscopicity (Sect. 3.2) and acts as a catalyst in $\mathrm{OM}_{\mathrm{AR}}$ formation. It can be wholly or partially titrated by ammonia or it can react with reactive organic compounds to form OS. The formation of OS from the esterification of sulfate with reactive organic functional groups leads to a reduction in $\left[\mathrm{H}^{+}\right]$and $\mathrm{LWC}$ influencing subsequent $\mathrm{OM}_{\mathrm{AR}}$ formation (Im et al., 2014). Therefore, the formation of OS must be estimated in order to accurately predict SOA growth. Of the total sulfate present in the SHMP aerosol, we assume that the sulfate which is not associated with ammonium $\left(C_{\mathrm{SO}_{4}^{2-}}^{\text {free }}=C_{\mathrm{SO}_{4}^{2-}}-0.5 \cdot C_{\mathrm{NH}_{4}^{+}}\right)$can form OS. The fraction of $C_{\mathrm{SO}_{4}^{2-}}^{\mathrm{free}}$ that forms OS is calculated using Eq. (6),

$\frac{C_{\mathrm{SO}_{4}^{2-}}^{\mathrm{OS}}}{C_{\mathrm{SO}_{4}^{2-}}^{\mathrm{free}}}=1-\frac{1}{1+f_{\mathrm{OS}} \frac{N_{\mathrm{OS}}}{C_{\mathrm{SO}_{4}^{2-}}^{\mathrm{free}}}}$

where $f_{\mathrm{OS}}$ is a semiempirical parameter determined to be 0.07 by Im et al. (2014) by fitting the $\left[\mathrm{H}^{+}\right]$predicted by UNIPAR to the measured $\left[\mathrm{H}^{+}\right]$in toluene $\mathrm{SOA}$, as a measure of OS formation, using the C-RUV method of Li et al. (2015). $f_{\text {OS }}$ was validated for isoprene SOA using the experimental data of this study (Sect. 4.1). $N_{\mathrm{OS}}$ is the number of OSforming functional groups present in the aerosol phase. The functional groups that have been shown to form OS are alcohols (Eddingsaas et al., 2012; Li et al., 2015; Minerath et al., 2008; Zhang et al., 2012), aldehydes (Liggio et al., 2005) and epoxides (Surratt et al., 2010). Alcohols and aldehydes can react with sulfate in a single position, while epoxides react with sulfate in two positions following ring opening in the aerosol phase. The average number of reaction positions with sulfate is determined for each $i_{m, n}$, and then $N_{\mathrm{OS}}$ is calculated as the product of the molar concentration and the reaction positions of $i_{m, n}$. Finally, $C_{\mathrm{SO}_{4}^{2-}}^{\mathrm{OS}}$ is removed from $C_{\mathrm{SO}_{4}^{2-}}^{\text {free }}$ so that $\mathrm{LWC}$ and $\left[\mathrm{H}^{+}\right]$can be recalculated for the next time step. As OS form, both $\mathrm{LWC}$ and $\left[\mathrm{H}^{+}\right]$are reduced.

As was noted in the "Experimental methods" section, the C-RUV method measures dialkylsulfates, which are neutral, and not alkyl bisulfates, which are strong acids. Therefore, the predicted OS in UNIPAR refer to dialkyl sulfates since $f_{\text {OS }}$ was semiempirically determined using this method.

\subsubsection{OM from partitioning $(\mathrm{OM})$}

$\mathrm{OM}_{\mathrm{P}, i}$ is calculated using the module developed by Schell et al. (2001) modified to account for the assumed nonvolatility and irreversibility of $\mathrm{OM}_{\mathrm{AR}}$. After $\mathrm{OM}_{\mathrm{AR}}$ formation, the amount of the remaining $C_{\mathrm{T}, i}$ of each lumping group that partitions between the gas and the SHMP aerosol is calculated as a function of the effective gas-phase saturation concentration of $i_{m, n}\left(C_{g, i}^{*}=1 / K_{\mathrm{mix}, i}\right)$ using a mass balance following Eq. (7),

$$
\begin{aligned}
& \mathrm{OM}_{\mathrm{P}, i}= \\
& {\left[\left(C_{\mathrm{T}, i}-\mathrm{OM}_{\mathrm{AR}, i}\right)-C_{\mathrm{g}, i}^{*} \frac{\frac{C_{\mathrm{mix}, i}}{\mathrm{MW}_{i}}}{\sum_{i}\left(\frac{C_{\mathrm{mix}, i}}{\mathrm{MW} i}+\frac{\mathrm{OM}_{\mathrm{AR}, i}}{\mathrm{MW}_{\mathrm{oli}, i}}\right)+\mathrm{OM}_{\mathrm{O}}}\right],}
\end{aligned}
$$

where $\mathrm{MW}_{k}$ and $\mathrm{MW}_{\text {oli }}$ are the molecular weight $\left(\mathrm{g} \mathrm{mol}^{-1}\right)$ of the lumping species and the dimer of the lumping species, respectively, and $\mathrm{OM}_{\mathrm{O}}$ is the preexisting organic mass $\left(\mathrm{mol} \mathrm{m}^{-3}\right)$. The system of nonlinear equations is solved iteratively, and the calculated $\mathrm{OM}_{\mathrm{P}, i}$ are summed to get the total $\mathrm{OM}_{\mathrm{P}}$ for each $\Delta t$. Unlike when $i_{m, n}$ partitions into an organic only phase $(\gamma=1), \gamma_{\text {mix }, i}$ is used in calculating $C_{\mathrm{g}, i}^{*}$ to account for the nonideality of $i_{m, n}$ partitioning into the SHMP aerosol (Sect. 3.2). The remaining concentration $\left(C_{\mathrm{T}, i}-\mathrm{OM}_{\mathrm{AR}, i}\right)$ is passed to the next time step and combined with the newly formed $i_{m, n}\left(\Delta \mathrm{VOC} \cdot \alpha_{i}\right)$.

\section{Results and discussion}

\subsection{Model evaluation: SOA yield, $\mathrm{O}$ : $\mathrm{C}$ and organosulfate formation}

The ability of UNIPAR to simulate the SOA formation from isoprene photooxidation in the presence and absence of acidic inorganic seeds under low initial $\mathrm{VOC} / \mathrm{NO}_{x}$ was determined through comparison of the simulated $\mathrm{OM}_{\mathrm{T}}$ and experimental $\mathrm{OM}$ formation $\left(\mathrm{OM}_{\mathrm{exp}}\right)$. All $\mathrm{OM}_{\mathrm{exp}}$ were corrected for particle wall loss. Figure 3 shows measured and predicted SOA formation in the presence and absence of SA at initial VOC $/ \mathrm{NO}_{x}$ of $\sim 17$ for ISO1 and SA1 and 32 for ISO2 and SA2. The experiments performed in the absence of inorganic seed (ISO1 and ISO2) are used to test the prediction of organic-only oligomerization by UNIPAR. SOA formation is reasonably predicted in the absence of an inorganic aqueous phase for both experimental conditions with a maximum SOA yield $\left(Y_{\mathrm{SOA}}=\Delta \mathrm{OM}_{\mathrm{exp}} / \Delta \mathrm{Iso}\right)$ of 0.025 and 0.007 for ISO1 and ISO2, respectively. These SOA yields are similar to those of reported literature values for isoprene in the absence of acidic seeds (Dommen et al., 2006). The model marginally overestimates the SOA formation at the beginning of each chamber run, but the modeled $\mathrm{OM}_{\mathrm{T}}$ falls within the range of error of $\mathrm{OM}_{\exp }$ once the rate of SOA formation stabilizes and reaches a maximum. $\mathrm{OM}_{\mathrm{AR}}$ makes up the majority of $\mathrm{OM}_{\mathrm{T}}$ (>65\% in ISO1 and ISO2). 

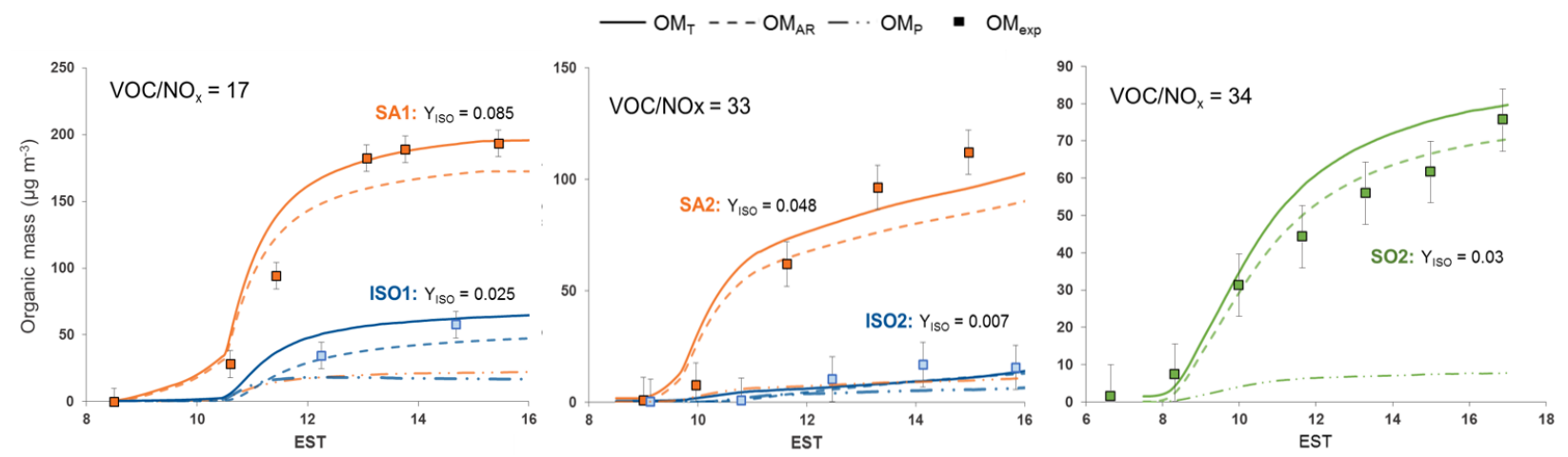

Figure 3. Time profiles of the experimentally measured and simulated SOA mass concentrations resulting from the photooxidation of isoprene. Data from experiments performed in the absence of inorganic seed are shown in blue, in the presence of sulfuric acid in orange, and in the presence of inorganic seed generated from $\mathrm{SO}_{2}$ photooxidation in green. Solid, dashed and dashed-dotted lines represent the simulated total organic mass $\left(\mathrm{OM}_{\mathrm{T}}\right)$, organic mass from aerosol phase reactions $\left(\mathrm{OM}_{\mathrm{AR}}\right)$ and organic mass from partitioning $(\mathrm{OM})$, respectively. The experimentally measured organic mass $\left(\mathrm{OM}_{\mathrm{exp}}\right)$ is shown with square markers and is corrected for particle wall loss. The VOC / NO $x$ ratios $\left(\mathrm{ppbC} \mathrm{ppb}^{-1}\right)$ are shown for each experiment.

While the oligomeric products contributing to isoprene SOA mass in the absence of an inorganic aqueous phase have not been fully elucidated for low- $\mathrm{NO}_{x}$ conditions, previous studies have shown that oligomers contribute a large fraction of the total mass in all oxidation conditions (low $\mathrm{NO}_{x}$, high $\mathrm{NO}_{x}, \mathrm{O}_{3}$ ) with the majority of products having molecular weights larger than $200 \mathrm{~g} \mathrm{~mol}^{-1}$ (Nguyen et al., 2010, 2011; Surratt et al., 2006). Furthermore, UNIPAR predicts that approximately $70 \%$ of the $\mathrm{OM}_{\mathrm{T}}$ is from lumping group $3 \mathrm{OS}_{\mathrm{p}}-\mathrm{M}$, of which more than $93 \%$ of the mass contribution is organic peroxides (MCM products $\mathrm{C} 510 \mathrm{OOH}(\sim 40 \%)$, $\mathrm{C} 57 \mathrm{OOH}(\sim 27 \%)$, C58OOH $(\sim 15 \%)$ and HMACROOH (11\%); structures shown in Fig. S7 of the Supplement). This is close to the measurements of Surratt et al. (2006), in which $61 \%$ of the total mass in the absence of seeds is from organic peroxides.

The presence of SA seeds (shown in orange in Fig. 3) greatly increases yields under both experimental conditions, resulting in $Y_{\mathrm{SOA}}$ of 0.085 and 0.048 for SA1 and SA2, respectively, due to the dissolution of $i_{m, n}$ into a larger $M_{\text {mix }}$ resulting from increased LWC and increased $k_{\mathrm{AR}, i}$ attributed to lower particle $\mathrm{pH}$ (higher $\left[\mathrm{H}^{+}\right]$). Using the factor $y$ that was fit using experiment SA1 in Table 1 (Eq. 5 in Sect. 3.3.1), the model accurately predicts the $\mathrm{OM}_{\mathrm{T}}$ of experiment SA2 at a lower $\mathrm{VOC} / \mathrm{NO}_{x}$ in the presence of SA seed. Overall, $\mathrm{OM}_{\mathrm{AR}}$ is the dominant contributor to $\mathrm{OM}_{\mathrm{T}}$ for both sets contributing more than 65 and $85 \%$ in the absence and presence of SA, respectively. Also, the higher VOC / $\mathrm{NO}_{x}$ (lower $\mathrm{NO}_{x}$ ) of both ISO2 and SA2 resulted in lower $Y_{\mathrm{SOA}}$ than ISO1 and SA1, which is discussed further in Sect. 4.3. In experiment $\mathrm{SO}_{2}$ (Table 1), $\mathrm{SO}_{2}(\mathrm{~g})$ was introduced to the chamber instead of SA seed so that the model could be further tested under a situation more representative of the ambient atmosphere in which $\mathrm{SO}_{2}$ is oxidized to $\mathrm{SA}$. As can be seen in Fig. 3. (shown in green), the model also reasonably predicts the $\mathrm{OM}_{\mathrm{T}}$.

In addition to $\mathrm{OM}_{\mathrm{T}}, \mathrm{O}: \mathrm{C}$ and $C_{\mathrm{SO}_{4}^{2-}}^{\mathrm{OS}}$ were also predicted using the model. The predicted $C_{\mathrm{SO}_{4}^{2-}}^{\mathrm{OS}}$ is important due to the consumption of sulfate that leads to an increase in particle $\mathrm{pH}$ and a reduction in $\mathrm{LWC}$. In experiment $\mathrm{SA} 2, \mathrm{C}_{\mathrm{SO}_{4}^{2-}}^{\mathrm{OS}}$ was measured using the C-RUV method, allowing for comparison to the model (refer to Sect. 2 for C-RUV method description). Figure 4 shows time series of the model predicted and measured $C_{\mathrm{SO}_{4}^{2-}}^{\mathrm{OS}}$ along with $C_{\mathrm{SO}_{4}^{2-}}$ and $C_{\mathrm{NH}_{4}^{+}}$(model values and experimental values measured by the PILS-IC), the measured $\mathrm{RH}$ and the predicted particle $\mathrm{pH}$. OS are reversible in the sampling conditions of the PILS (Li et al., 2015), as is suggested by the near-stable $C_{\mathrm{SO}_{4}^{2-}}$ in Fig. 4. Once SOA formation starts, OS quickly form. The measured $C_{\mathrm{SO}_{4}^{2-}}^{\mathrm{OS}}$ is reasonably well predicted by the model, with the predicted value being within the range of error once SOA mass stabilizes. The predicted $\mathrm{pH}$ is relatively stable in the first hour of the experiment because the effects of decreasing $\mathrm{RH}$ (and LWC) and increasing $C_{\mathrm{NH}_{4}^{+}}$counteract each other, but once SOA formation starts $\mathrm{pH}$ increases rapidly due to titration by $\mathrm{NH}_{3}$ produced from the chamber walls, the consumption of $C_{\mathrm{SO}_{4}^{2-}}$ by OS formation and the dilution of $\left[\mathrm{H}^{+}\right]$by SOA mass. Overall, the predicted $\mathrm{pH}$ starts at -0.73 and increases to 0.65 at the end of the experimental run, which is within the range of ambient aerosol $\mathrm{pH}$ measured by Guo et al. (2015) in the SE US (mean: 0.94; min: -0.94; max: 2.23).

While the $\mathrm{O}: \mathrm{C}$ of the experimental SOA was not measured, the simulated $\mathrm{O}: \mathrm{C}$ can be compared to literature values which range from 0.69 to 0.88 (Bertram et al., 2011; Chen et al., 2011; Kuwata et al., 2013). UNIPAR estimates the $\mathrm{O}: \mathrm{C}$ ratio using $\mathrm{O}: \mathrm{C}_{i}$ and mole fractions of each species 


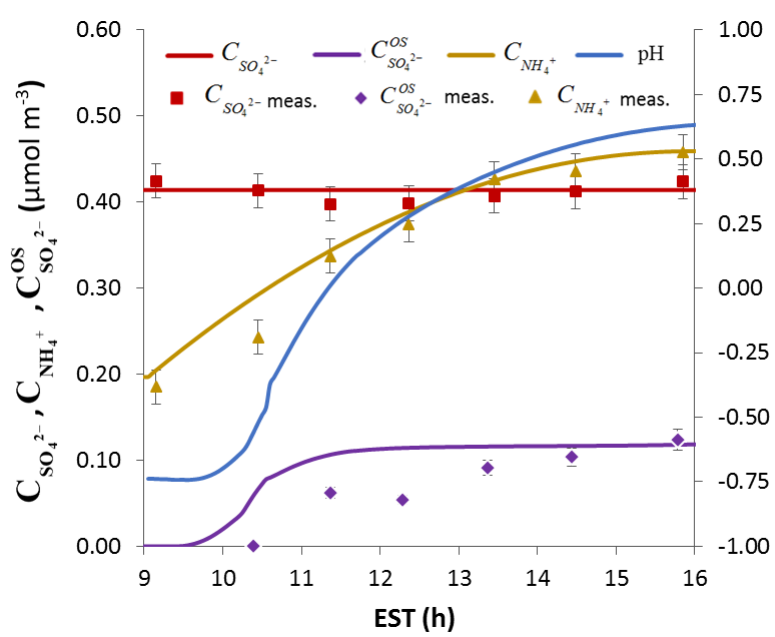

Figure 4. Time profiles of the total inorganic sulfate $\left(C_{\mathrm{SO}_{4}^{2-}}\right)$ and ammonium $\left(C_{\mathrm{NH}_{4}^{+}}\right)$concentrations, and $\mathrm{RH}$ from experiment $\mathrm{SA} 2$, along with the measured and model predicted concentrations of the sulfate associated with organosulfates $(\mathrm{OS})\left(\mathrm{C}_{\mathrm{SO}_{4}^{2-}}^{\mathrm{OS}}\right)$, and the predicted particle $\mathrm{pH}$. The experimentally measured sulfate and ammonium concentrations $\left(C_{\mathrm{SO}_{4}^{2-}}\right.$ meas. and $C_{\mathrm{NH}_{4}^{+}}$meas.) are shown along with the model values.

in the aerosol phase but does not account for changes that may result from oligomerization, hydration or OS formation. In the presence of untitrated SA, the modeled $\mathrm{O}: \mathrm{C}$ is 0.69 which is the lower end of the range of literature values. With increasing titration, changes in composition lead to higher overall predicted $\mathrm{O}: \mathrm{C}$. In SA1, SA is partially titrated by $\mathrm{NH}_{3}^{+}$over the course of the experiment and the resulting $\mathrm{O}: \mathrm{C}$ is 0.84 . For ISO1 and ISO2, the $\mathrm{O}: \mathrm{C}$ ratios are 0.92 and 0.98 , which is higher than the reported values. This is due to the predicted SOA being comprised of a few compounds, with $\mathrm{O}: \mathrm{C}$ near 1 , without considering the change of molecular structures via aerosol phase reactions. Chen et al. (2011) showed a similar result in that the $\mathrm{O}: \mathrm{C}$ ratio of monomeric products in isoprene SOA is higher than that of oligomers.

\subsection{Isoprene SOA yield and the influence of VOC / NO $x$ and inorganic composition}

In the following sections the model is used to investigate the influence of $\mathrm{VOC} / \mathrm{NO}_{x}, \mathrm{LWC}$ and $\left[\mathrm{H}^{+}\right]$on isoprene $Y_{\mathrm{SOA}}$ and composition. The experimental conditions of SA1 $(\mathrm{RH}$, $T, \Delta \mathrm{ISO})$ are used in all of these simulations unless otherwise specified.

Recent studies have investigated the effect of $\mathrm{NO}_{x}$ on the SOA formation of isoprene for the high- $\mathrm{NO}_{x}$ regime $\left(\mathrm{VOC} / \mathrm{NO}_{x}<5.5\right)$ and in the absence of $\mathrm{NO}_{x}$ (A. W. H. Chan et al., 2010; Kroll et al., 2006; Xu et al., 2014) and found that the $Y_{\text {SOA }}$ of isoprene is nonlinearly related to $\mathrm{VOC} / \mathrm{NO}_{x}$, with $Y_{\mathrm{SOA}}$ being highest at interme-

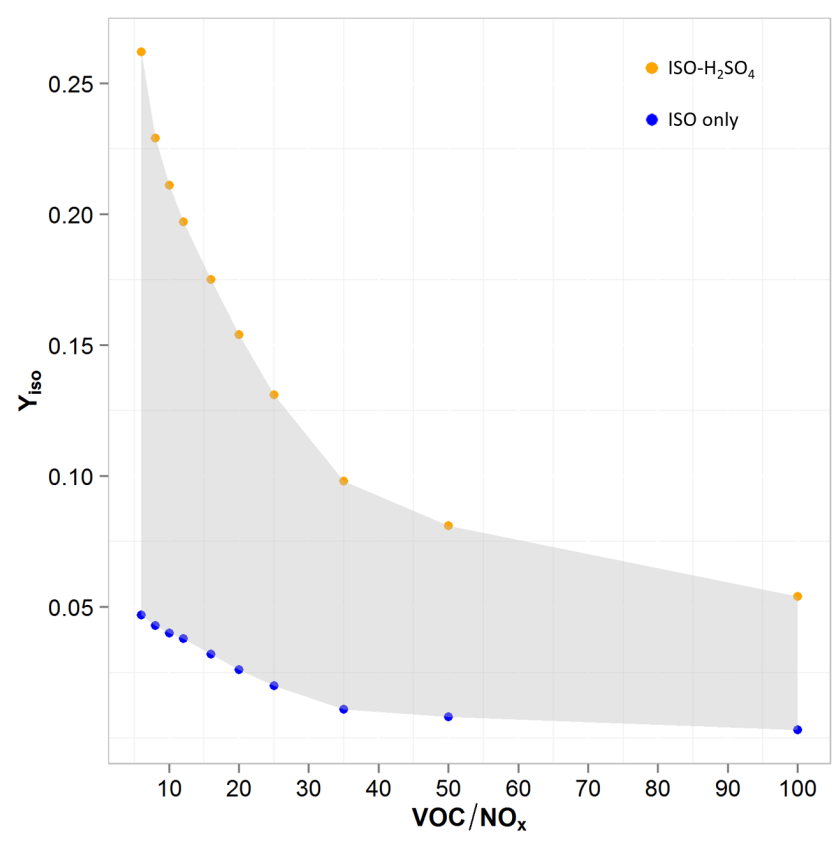

Figure 5. Simulated isoprene SOA yields $\left(Y_{\mathrm{SOA}}=\Delta \mathrm{OM} / \Delta \mathrm{Iso}\right)$ as a function of VOC / $\mathrm{NO}_{x}\left(\mathrm{ppbC} \mathrm{ppb}^{-1}\right)$ for values 10 to 100 . The simulations were performed using the experimental conditions of SA1 (Table 1) without inorganic seed (blue) and in the presence of untitrated sulfuric acid (orange).

diate $\mathrm{NO}_{x}$ conditions $\left(\mathrm{VOC} / \mathrm{NO}_{x}=\sim 2\right)$. However, very little investigation has been performed on isoprene SOA formation within the low- $\mathrm{NO}_{x}$ regime $\left(\mathrm{VOC} / \mathrm{NO}_{x}>5.5\right.$ and $\mathrm{NO}_{x}>0 \mathrm{ppb}$ ) of this study, which is typical of rural areas downwind of urban centers (Finlayson-Pitts and Pitts Jr., 1993). To investigate the influence of the $\mathrm{NO}_{x}$ level on $Y_{\mathrm{SOA}}$ in this range, simulations were performed in which the $\mathrm{VOC} / \mathrm{NO}_{x}$ ratio was increased incrementally from 10 to 100 with SA-seeded SOA without titration and isoprene-only SOA. The $Y_{\mathrm{SOA}}$ of each simulation are plotted in Fig. 5. Overall, increasing $\mathrm{NO}_{x}$ within this range (decreasing VOC $/ \mathrm{NO}_{x}$ ) increases $Y_{\mathrm{SOA}}$ both with and without acidic seeds, which agrees with the general trend of Kroll et al. (2006) where intermediate $\mathrm{NO}_{x}$ conditions had higher $Y_{\mathrm{SOA}}$ than no- $\mathrm{NO}_{x}$ conditions. However, the degree of the increase in $Y_{\mathrm{SOA}}$ with increasing $\mathrm{NO}_{x}$ is different for the isoprene-only SOA and the SOA formed in the presence of SA seeds, which, to the best of our knowledge, has not previously been shown.

$Y_{\text {SOA }}$ increases much more rapidly with increasing $\mathrm{NO}_{x}$ in the presence of SA seeds, which is due to an increase in the relative contribution of reactive species. $\mathrm{RO}$ radicals produced from the reaction of $\mathrm{RO}_{2}$ radicals with $\mathrm{NO}$ can lead to multifunctional carbonyls via reaction with oxygen and also simple carbonyls such as glyoxal and methylglyoxal through the fragmentation of $\mathrm{RO}$ radicals. These products are all highly reactive in the aerosol phase and produce 
$\mathrm{OM}_{\mathrm{AR}}$. Furthermore, some late-generation $\mathrm{RO}_{2}$ radicals, whose precursors are formed from the RO pathway (high $\mathrm{NO}$ ), react with $\mathrm{HO}_{2}$ to form low-volatility organic peroxides with alcohol functional groups and an aldehyde $\left(3 \mathrm{OS}_{\mathrm{p}}-\mathrm{M}\right.$ : $\mathrm{C} 510 \mathrm{OOH}, \mathrm{C} 57 \mathrm{OOH}, \mathrm{C} 58 \mathrm{OOH}, \mathrm{HMACROOH}$ in MCM; Sect. S7). Therefore, increases in $\mathrm{NO}_{x}$ within the simulation condition (VOC / $\mathrm{NO}_{x}$ 10-100) of this study leads to increased $Y_{\mathrm{SOA}}$ with higher sensitivity to $\mathrm{VOC} / \mathrm{NO}_{x}$ in the presence of inorganic seed. Figure S5 shows the stoichiometric mass coefficients $\left(\alpha_{i}\right)$ of important products as a function of $\mathrm{VOC} / \mathrm{NO}_{x}$.

$Y_{\mathrm{SOA}}$ is also dynamically related to inorganic compositions. SOA formation in the absence of inorganic seed is primarily a function of the characteristics of $i_{m, n}$ and the impact of LWC on isoprene SOA is minimal. However, under ambient conditions SOA will typically be formed in the presence of inorganic aerosol. Variations in the inorganic aerosol composition $\left(C_{\mathrm{SO}_{4}^{2-}}\right.$ and $\left.C_{\mathrm{NH}_{4}^{+}}\right)$and $\mathrm{RH}$ lead to significant changes in LWC and $\mathrm{pH}$. At high LWC, the total volume of absorptive mass $\left(M_{\text {mix }}\right)$ increases, allowing for hydrophilic $i_{m, n}$ to partition into the aerosol in significant amounts and engage in aerosol phase reactions. Additionally, highly reactive species such as IEPOX will react to rapidly form SOA in the presence of $\left[\mathrm{H}^{+}\right]$(Gaston et al., 2014). In Fig. 6 the simulated $Y_{\mathrm{SOA}}$ is plotted as a function of the fractional free sulfate (FFS), $\left[\left(C_{\mathrm{SO}_{4}^{2-}}-0.5 C_{\mathrm{NH}_{4}^{+}}\right) / C_{\mathrm{SO}_{4}^{2-}}\right]$ and $\mathrm{RH}$. Unlike $\mathrm{pH}$, which is very difficult to measure, $C_{\mathrm{SO}_{4}^{2-}}, C_{\mathrm{NH}_{4}^{+}}$and $\mathrm{RH}$ data are widely available and easy to measure, which is why FFS and RH were used in Fig. 6. Using an ion balance such as FFS alone has been shown to be not representative of actual particle pH (Guo et al., 2015), but providing both FFS and $\mathrm{RH}$ allows for an estimation of $\mathrm{pH}$ within an inorganic thermodynamic model and ease of use by future studies.

It is difficult to decouple the effects of $C_{\mathrm{SO}_{4}^{2-}}, \mathrm{LWC}$ and $\mathrm{pH}$ since sulfate ultimately influences both $\mathrm{LWC}$ and $\mathrm{pH}$, but Fig. 6 can be used to help elucidate the influence of these effects in UNIPAR. For AS seed (FFS $=0.0$ ), sulfate is entirely titrated by ammonia and the lowest $Y_{\text {SOA }}$ occurs below the ERH. As the RH increases, AS becomes deliquesced and the LWC gradually rises leading to an increase in $Y_{\mathrm{SOA}}$. This is true for the predictions at all small values of FFS due to the increase in the total volume of absorptive mass $\left(M_{\text {mix }}\right)$ associated with increasing LWC, allowing for hydrophilic $i_{m, n}$ to partition into the aerosol in significant amounts and engage in aerosol phase reactions. However, as the amount of $C_{\mathrm{NH}_{4}^{+}}$ decreases (FFS $<0.7$, highly acidic), the effect of increasing LWC reverses, and $Y_{\text {SOA }}$ decreases with increasing LWC due to the dilution of $C_{\mathrm{SO}_{4}^{2-}}$ and the resulting increase in $\mathrm{pH}$. If $\mathrm{RH}$ is held constant, varying FFS allows for investigation of the effect of $\mathrm{pH}$ on $Y_{\mathrm{SOA}}$. Increasing FFS or decreasing $\mathrm{pH}$ at constant RH leads to a rapid increase in $Y_{\mathrm{SOA}}$ at all RHs due to an increase in the SOA formation from the acid-catalyzed reactions of species such as IEPOX. Therefore, sulfate mod-

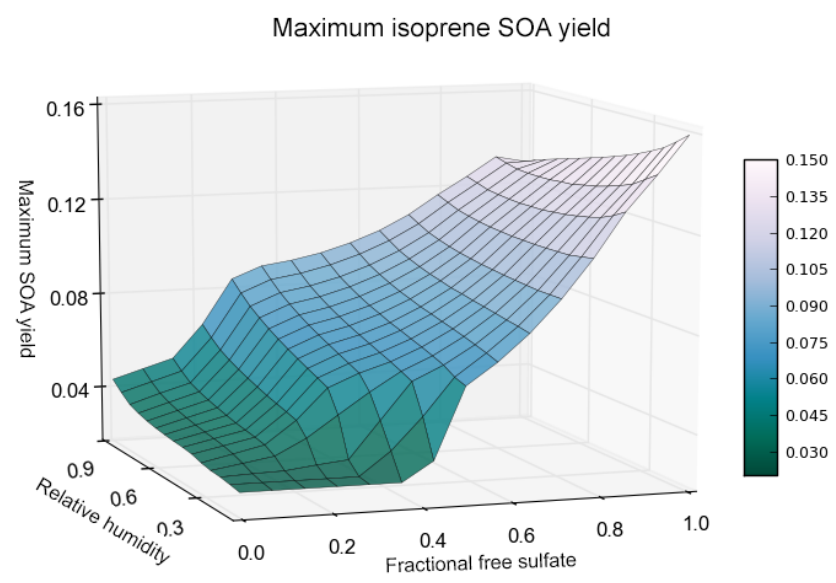

Figure 6. Simulated isoprene $\mathrm{SOA}$ yields $\left(Y_{\mathrm{SOA}}=\Delta \mathrm{OM} / \Delta \mathrm{Iso}\right)$ as a function of relative humidity $(\mathrm{RH})$ and fractional free sulfate $\left(\mathrm{FFS}=\left(C_{\mathrm{SO}_{4}^{2-}}-0.5 C_{\mathrm{NH}_{4}^{+}}\right) / C_{\mathrm{SO}_{4}^{2-}}\right)$. Using the experimental conditions of SA1, the RH and FFS were varied to determine the impact of acidity and aerosol liquid water content on $Y_{\mathrm{SOA}}$.

ulates $Y_{\mathrm{SOA}}$ within UNIPAR by controlling $\mathrm{LWC}$ and $\left[\mathrm{H}^{+}\right]$, which influence $k_{\mathrm{AR}, i}$ (Eq. 5). The consumption of sulfate by OS formation is accounted for in UNIPAR through a reduction in acidity and LWC, but the role of sulfate as a nucleophile in reactive uptake is not directly accounted for.

\subsection{Simulated composition of isoprene SOA}

Analysis of the contributions of each $i_{m, n}$ to the overall $\mathrm{OM}_{\mathrm{T}}$ allows for a determination of the species that are significant in isoprene SOA for various inorganic compositions. Four simulations were performed at $60 \% \mathrm{RH}$ with $\mathrm{AS}$ and SA seeds at org: sulf of 0.5 and 1.5 to capture the differences in composition as a result of changes in $\mathrm{LWC},\left[\mathrm{H}^{+}\right]$and $M_{\text {mix }}$.

The aerosol mass fraction of each $i_{m, n}\left(\mathrm{MF}_{i}\right)$ under the simulated conditions are shown in Fig. 7. IEPOX has been demonstrated to be an important precursor to ambient (Budisulistiorini et al., 2015; M. N. Chan et al., 2010) and laboratory-generated (Lin et al., 2012; Paulot et al., 2009) isoprene SOA leading to the formation of 2-methyltetrols (Surratt et al., 2010), OS (Liao et al., 2015), and other species through aerosol phase reactions in which IEPOX products contribute up to $33 \%$ of ambient OM in the southeast US (Budisulistiorini et al., 2013). The formation of IEPOXderived SOA has been shown to be primarily from the reactive uptake in the presence of LWC and $\left[\mathrm{H}^{+}\right]$but is most highly correlated with aerosol acidity (Gaston et al., 2014). In Fig. 7, it can be seen that the $\mathrm{MF}_{i}$ of IEPOX-derived SOA is higher in the presence of $\left[\mathrm{H}^{+}\right]$. When accounting for the yield of each system, the total formation of IEPOXderived SOA is much greater in the presence of SA seed than AS seed. Additionally, the $\mathrm{MF}_{i}$ of IEPOX-derived SOA falls within the range measured in literature. When org: sulf increases from 0.5 to 1.5 in the presence of SA, the reduction of 


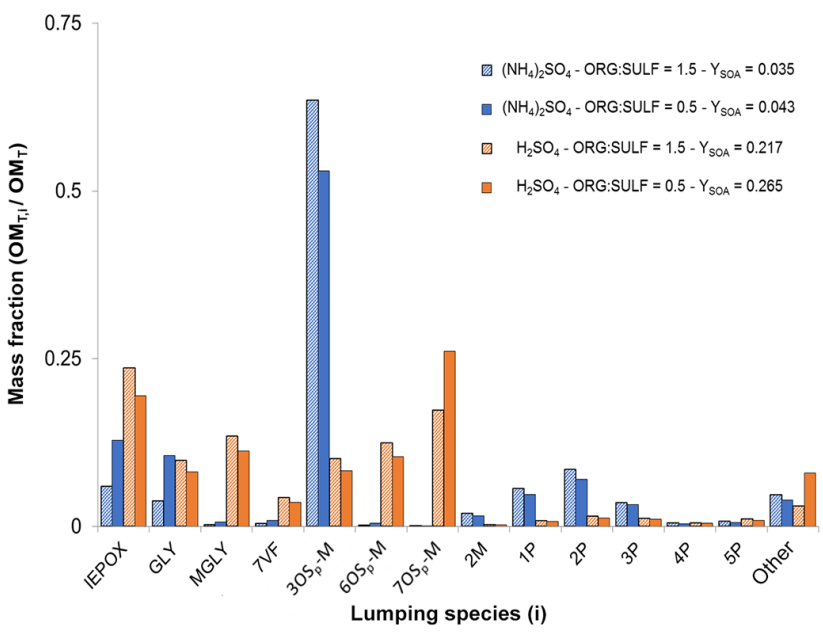

Figure 7. The mass fraction $\left(\mathrm{MF}_{i}=\mathrm{OM}_{\mathrm{T}, i} / \mathrm{OM}_{\mathrm{T}}\right)$ of each lumping species, $i$, that contribute significantly to the simulated isoprene SOA in the presence of ammonium sulfate, $\left(\mathrm{NH}_{4}\right)_{2} \mathrm{SO}_{4}$, and sulfuric acid seeds, $\mathrm{H}_{2} \mathrm{SO}_{4}$, at organic-to-sulfur mass ratios of 0.5 and 1.5. The $\mathrm{MF}_{i}$ of the remaining lumping groups are summed and included in "OTHER". The $\mathrm{MF}_{i}, Y_{\mathrm{SOA}}$ and org : sulf are calculated at the point of maximum SOA mass with an initial $\mathrm{VOC} / \mathrm{NO}_{x}$ ratio of $\sim 17$ (experiment SA1 in Table 1).

$\mathrm{MF}_{i}$ of IEPOX products is due to the increasing contribution of other $i_{m, n}$ (7OS $\mathrm{p}-\mathrm{M}$ and OTHER), while the mass contribution of IEPOX remains similar. The $\mathrm{MF}_{i}$ of glyoxal (GLY) is significant for all four simulations but increases with the growth of $M_{\text {mix }}$ due to its high aqueous solubility and tendency to form hydrates that can form oligomers.

In the absence of acidity, $k_{\mathrm{AR}, i}$ is relatively small and the $\mathrm{MF}_{i}$ is primarily a function of the gas phase concentration, volatility and solubility of $i$. For example, in the ASseeded SOA simulations, $3 \mathrm{OS}_{\mathrm{p}}-\mathrm{M}$ (organic peroxides with both an aldehyde and alcohols; Figs. S3 and S7) contributes more than half of the total mass (Fig. 7) due to its high gas phase concentration and low volatility. As LWC and $k_{\mathrm{AR}, i}$ increase (AS to SA seed aerosol and org : sulf 1.5 to 0.5 ), more volatile and reactive $i_{m, n}$ is able to contribute to $\mathrm{MF}_{i}$. Therefore, the $\mathrm{MF}_{i}$ of $3 \mathrm{OS}_{\mathrm{p}}-\mathrm{M}$ is significantly reduced in SA-seeded SOA as other $i_{m, n}$ contribute in larger fractions. Overall, $\mathrm{OM}_{\mathrm{P}}$ only contributes a small fraction of the total $\mathrm{OM}_{\mathrm{T}}$, and the $\mathrm{MF}_{i}$ of the partitioning species generally decreases with an increasing contribution of other species at higher $\mathrm{LWC}$ and $\left[\mathrm{H}^{+}\right]$.

\subsection{Model sensitivity, uncertainty and limitations}

UNIPAR utilizes the chemical structures provided by MCM to estimate the thermodynamic properties of the gas phase products, which are lumped based on their calculated vapor pressure (eight groups) and aerosol phase reactivity (six groups). However, since not all atmospheric reactions have been studied in detail, MCM determines the products and ki- netics of unstudied reactions using the known degradation mechanisms of similar chemical species. Pinho et al. (2005) evaluated the isoprene mechanism of MCM v3 by comparing the oxidation of isoprene and its products methacrolein and methylvinyl ketone to chamber data. The model performed reasonably well for these limited products, but a large amount of uncertainty remains in regard to the prediction of the hundreds of other isoprene-derived products. Furthermore, the lumping approach of UNIPAR uses a fixed gas phase composition set at the maximum $\mathrm{HO}_{2} / \mathrm{NO}$ for each VOC $/ \mathrm{NO}_{x}$ ratio. This approach does not account for changes to the gas phase composition that occur due to continued oxidation.

Deviation of the estimated $p_{\mathrm{L}, i}^{o}$ from the actual $p_{\mathrm{L}, i}^{o}$ due to the uncertainty of the group contribution method (Sect. 3.1) can change the lumping assignment affecting both $\mathrm{OM}_{P}$ and $\mathrm{OM}_{\mathrm{AR}}$. The uncertainty associated with the group contribution method used for $p_{\mathrm{L}, i}^{o}$ estimation is a factor of 1.45 (Joback and Reid, 1987; Stein and Brown, 1994; Zhao et al., 1999). The temperature dependency of each lumping group as is calculated as a function of the enthalpy of vaporization $\left(\Delta H_{\text {vap }}\right)$ and also has an associated uncertainty that can affect the model prediction. The error of this method is $2.6 \%$ (Kolská et al., 2005). To determine the model sensitivity to these parameters, simulations of SA1 were performed by increasing and decreasing $p_{\mathrm{L}, i}^{o}$ and $\Delta H_{\mathrm{vap}}$ by a factor of 1.5 and 1.1, respectively. The change in $\mathrm{OM}_{\mathrm{T}}$ from the baseline for each simulation is shown in Fig. S6. Increasing and decreasing $p_{\mathrm{L}, i}^{o}$ by a factor of 1.5 results in a 32.03 and $-26.41 \%$ change, respectively, while modifying $\Delta H_{\text {vap }}$ only leads to $\pm 0.27 \%$ change.

The thermodynamic model AIOMFAC was employed to generate a simplified parameterization to estimate $\gamma_{\text {mix }, i}$ in the SHMP isoprene SOA as a function of $\mathrm{O}: \mathrm{C}$, org : sulf, $\mathrm{RH}$ and $V_{\text {mol }}$. AIOMFAC is a valuable tool for predicting the activity coefficients of complex mixtures, but it has substantial uncertainty resulting from limitations of the database used in development and the error associated with the underlying modules. Moreover, the expected accuracy is limited further by the regression performed in UNIPAR. For the condition simulated by UNIPAR, $\gamma_{\text {mix }, i}$ are all near unity $(0.65-1.75)$. Considering the characteristics of an SHMP aerosol, a factor of 1.5 was applied to the predicted $\gamma_{\text {mix }, i}$ and the resulting change in $\mathrm{OM}_{\mathrm{T}}$ is $-16.22 \% /+32.00 \%$ (Fig. S6), which is similar to the model sensitivity to $p_{\mathrm{L}, i}^{o}$.

The other parameter largely affecting the simulated SOA formation in UNIPAR is $k_{\mathrm{AR}, i}$, which is calculated primarily as a function of $\mathrm{LWC},\left[\mathrm{H}^{+}\right]$and reactivity of $i_{m, n}$ (Sect. 3.3.1). Estimations of LWC and $\left[\mathrm{H}^{+}\right]$are performed by the inorganic thermodynamic model E-AIM. Similar to AIOMFAC, the accuracy of E-AIM will depend on the underlying assumptions and the database used in development. For LWC, the predictions of E-AIM are consistent with other inorganic thermodynamic models and are based on widely used, critically reviewed water activity data (Zhang et 
al., 2000). However, inorganic thermodynamic models vary widely in predicting $\left[\mathrm{H}^{+}\right]$especially at low $\mathrm{RH}$. This is especially true for ammonia-rich inorganic salts at low RH. Corrections for the ammonia-rich predictions of $\left[\mathrm{H}^{+}\right]$were applied based on the results of $\mathrm{Li}$ and Jang (2012) in which aerosol $\left[\mathrm{H}^{+}\right]$was measured using a filter-based colorimetry method coupled with a PILS-IC. The total uncertainty of this method is approximately $18 \%$. There is also uncertainty stemming from the flow chamber study that was used to fit the coefficients used in predicting $k_{\mathrm{AR}, i}$. To determine the possible sensitivity of the model to the combined uncertainty of the corrected E-AIM and the function used to predict $k_{\mathrm{AR}, i}$, a factor of 2.0 was applied to simulations and the resulting change in $\mathrm{OM}_{\mathrm{T}}$ is approximately $\pm 13 \%$ (Fig. S6).

Furthermore, not all recent advancements in the understanding of SOA formation mechanisms are accounted for by UNIPAR, including but not limited to SOA viscosity, nighttime chemistry of nitrate radicals $\left(\mathrm{NO}_{3}^{*}\right)$, and SVOC wall loss. Virtanen et al. (2010) reported that biogenic SOA can exist as amorphous solids or a glassy state, which can lead to deviations from equilibrium processes, but Song et al. (2015) found that isoprene-derived SOA is of low viscosity under the range of ambient RH. Thus, the impact of viscosity on isoprene SOA is minimal. The nighttime reaction of isoprene with $\mathrm{NO}_{3}^{*}$ has been found to lead to significant SOA formation due to the formation of stable primary organonitrate $(\mathrm{ON})$. $\mathrm{Ng}$ et al. (2008) measured that SOA yields up to $23.8 \%$ from the dark chamber reaction of isoprene and $\mathrm{NO}_{3}^{*}$ under dry conditions $(<10 \% \mathrm{RH})$, while Rollins et al. (2012) linked $\mathrm{NO}_{3}^{*}$ chemistry to ambient, nighttime SOA production with 27 to $40 \%$ of nighttime $\mathrm{OM}$ growth from $\mathrm{ON}$. Under low- $\mathrm{NO}_{x}$ conditions, isoprene photooxidation has been shown to produce primarily tertiary ON in both the gas phase and through aerosol phase epoxide reactions (Eddingsaas et al., 2010; Paulot et al., 2009). Darer et al. (2011) investigated the stability of primary and tertiary $\mathrm{ON}$ and found the tertiary $\mathrm{ON}$ to be highly unstable and to rapidly convert to OS and polyols in both neutral and acidic SOA. Therefore, it is unlikely that ON significantly contributes to the SOA investigated and modeled in this study. A number of recent studies have found that the loss of gas phase vapors to chamber walls can compete with gasparticle partitioning (Matsunaga and Ziemann, 2010; Zhang et al., 2014, 2015). Vapor wall loss was not accounted for in this study and thus the experimental SOA mass may be low biased. However, based on the conclusions of Zhang et al. (2015), the high volatility of isoprene products likely results in gas-particle partitioning outcompeting vapor wall loss in chambers with a large ratio of volume-to-surface area.

Another new development in the SOA formation is the discovery of the salting-in and salting-out of glyoxal and methylglyoxal (Waxman et al., 2015). While these effects are very interesting and likely influence the SOA formation of these species, they are not yet included within UNIPAR. The topic will be reconsidered for application within our model once these effects have been more comprehensively investigated for a wider range of relevant water-soluble organic molecules and inorganic aerosol compositions.

Some recent studies have also found that $\mathrm{C}_{2}-\mathrm{C}_{4}$ compounds (e.g. glyoxal) can form OS when neutral AS seeds are irradiated to produce sulfate radicals (Galloway et al., 2009; Nozière et al., 2010), but AS seeds are assumed to not form OS in UNIPAR. The primary purpose of OS prediction in the model is to account for the reduction of $\left[\mathrm{H}^{+}\right]$and $\mathrm{LWC}$, which influence subsequent reactions in the aqueous phase. However, in neutral AS seeds the formation of OS will not impact acidity. The only potential limitation of the current approach is the inability to predict the reduction in LWC if significant dialkyl sulfate formation occurs in wet AS seed. In the presence of acidic seeds, the photo-irradiated OS formation is likely accounted for as $f_{\mathrm{OS}}$ (Eq. 6) in UNIPAR was semiempirically determined using the total amount of dialkyl sulfate formed.

In the recent Southern Oxidant and Aerosol Study field campaign, Budisulistiorini et al. (2015) and Xu et al. (2015) found ambient isoprene SOA formation in the SE US to be most highly correlated with $C_{\mathrm{SO}_{4}^{2-}}$ and insensitive to $\left[\mathrm{H}^{+}\right]$ and LWC. However, in the summer months the aerosol of the SE US is highly acidic ( $\mathrm{pH}-1$ to 2 ) and high in LWC due to the high RH (>50\%) (Guo et al., 2015). Under these conditions, the formation of isoprene-derived SOA is not likely to be highly correlated with changes in $\mathrm{LWC}$ and $\left[\mathrm{H}^{+}\right]$ since both are always high. Yet when comparing neutral and acidic conditions, the presence of acidity has repeatedly been shown to lead to increases in $Y_{\text {SOA }}$ (Lin et al., 2012; Surratt et al., 2007). Additionally, Xu et al. (2015) found a reduction in isoprene-derived SOA with increased RH for the highly acidic aerosol of the campaign. A similar reduction with increasing RH is seen at high FFS in Fig. 6 due to the dilution of $C_{\mathrm{SO}_{4}^{2-}}$ and the corresponding $\left[\mathrm{H}^{+}\right]$by increases in LWC.

\section{Conclusions and atmospheric implications}

Under the assumption of SHMP aerosol, UNIPAR was able to simulate the low- $\mathrm{NO}_{x}$ SOA formation of isoprene from partitioning and aerosol phase reactions with and without an inorganic acid seed. The data used to validate the model were generated using the UF-APHOR outdoor chamber, which allows for day-long experiments under ambient sunlight, $T$ and RH. For the SOA formation of isoprene in the absence of deliquesced inorganic seeds, UNIPAR was able to predict the experimental $\mathrm{OM}_{\mathrm{T}}$ using the same approach that was applied to anthropogenic, aromatic VOCs in Im et al. (2014) without any modification. Differences between the SHMP SOA formed by isoprene in the presence of deliquesced inorganic seeds and LLPS SOA of the previous study required a slight reduction in $k_{\mathrm{AR}, i}$. After validating the model using the measured SOA formation of outdoor chamber experiments, simulations were performed to elucidate the sensitivity of $Y_{\text {SOA }}$ 
and composition to model parameters. From this analysis it was determined that the $Y_{\mathrm{SOA}}$ of isoprene and the resulting SOA composition is primarily a function of $\mathrm{VOC} / \mathrm{NO}_{x}$, $\left[\mathrm{H}^{+}\right]$and LWC. For the range of $\mathrm{VOC} / \mathrm{NO}_{x}$ investigated in this study $(\geq 10)$, increases in $\mathrm{NO}_{x}$ corresponded with increases in $Y_{\mathrm{SOA}}$ and a higher sensitivity to $\left[\mathrm{H}^{+}\right]$. This is due to the increased production of highly reactive carbonyls, such as glyoxal, and a more general shift to lower volatility (Fig. S6).

Changes in $\left[\mathrm{H}^{+}\right]$and LWC were shown to strongly influence $Y_{\text {SOA }}$ (Fig. 6). At a given $\mathrm{RH}$, increases in $\left[\mathrm{H}^{+}\right]$result in increased OM formation. For titrated acidic aerosol, increases in RH lead to gradual increases in $Y_{\mathrm{SOA}}$. However for highly acidic aerosol (FFS $\geq 0.75$ ), increases in RH decrease $Y_{\mathrm{SOA}}$ due to the dilution of $\left[\mathrm{H}^{+}\right]$. Overall, isoprene SOA formation was found to be most sensitive to $\left[\mathrm{H}^{+}\right]$, with the highest $Y_{\text {SOA }}$ occurring at high FFS and low RH.

Due to the pervasiveness of isoprene in the ambient atmosphere, any variation in $Y_{\mathrm{SOA}}$ will have a strong influence on the global SOA budget and needs to be accounted for by climate and air quality models. Since the experimental runs and simulations performed in this study were at concentrations beyond those of the ambient atmosphere, additional simulations were performed to estimate $Y_{\mathrm{SOA}}$ for conditions more representative of the ambient atmosphere. The $\Delta \mathrm{ISO}$ during each $\Delta t$ was assumed to be constant and estimated assuming a pseudo first-order reaction with $\mathrm{OH}$ using an isoprene concentration of $2.4 \mathrm{ppb}$ from the rural measurements of Wiedinmyer et al. (2001) and an $\mathrm{OH}$ concentration of $1.0 \times 10^{6}$ molecules $\mathrm{cm}^{-3}$. Using a $C_{\mathrm{SO}_{4}^{2-}}$ of $5.55 \mu \mathrm{g} \mathrm{m}^{-3}$ and $\mathrm{OM}_{\mathrm{o}}$ of $3 \mu \mathrm{g} \mathrm{m}^{-3}$ based on the nonurban continental composition of submicron particulate mass (PM) from the review of Heintzenberg (1989), two sets of simulations were performed for AS and ammonium bisulfate (ABS) at RHs of 30 and $60 \%$ and $\mathrm{VOC} / \mathrm{NO}_{x}=10$. The simulated $Y_{\mathrm{SOA}}$ of $\mathrm{AS}$ is $0.01695\left(\mathrm{OM}_{\mathrm{T}}=0.329 \mu \mathrm{g} \mathrm{m}^{-3}\right)$ and $0.0207\left(\mathrm{OM}_{\mathrm{T}}=0.402 \mu \mathrm{g} \mathrm{m}^{-3}\right)$, and that of ABS is 0.0446 $\left(\mathrm{OM}_{\mathrm{T}}=0.867 \mu \mathrm{g} \mathrm{m}^{-3}\right)$ and $0.0449\left(\mathrm{OM}_{\mathrm{T}}=0.873 \mu \mathrm{g} \mathrm{m}^{-3}\right)$ at 30 and $60 \% \mathrm{RH}$, respectively. The $\mathrm{OM}_{\mathrm{T}}$ formation and associated $Y_{\text {SOA }}$ was calculated after an 8-hour simulation. AS at $30 \% \mathrm{RH}$ is used as the baseline as it is below the ERH. Increasing the RH to $60 \%$ leads to a $22 \%$ increase in $Y_{\text {SOA }}$ for AS due to the increased LWC. The presence of ABS seeds and the resultant increase in $\left[\mathrm{H}^{+}\right]$leads to an increase of 163 and $165 \%$ in $Y_{\mathrm{SOA}}$ over the baseline at 30 and $60 \% \mathrm{RH}$, respectively. These results support the conclusion that the SOA formation of isoprene is more sensitive to $\left[\mathrm{H}^{+}\right]$than to $\mathrm{LWC}$ but dynamically related to both. Furthermore, while the SOA formation of isoprene may be reasonably predicted as a linear function of $\left[\mathrm{H}^{+}\right]$for a specific $\mathrm{RH}$ and $\mathrm{VOC} / \mathrm{NO}_{x}$, as is proposed by Surratt et al. (2007), a single linear relationship will not hold at a different $\mathrm{RH}$ for a single $\mathrm{VOC} / \mathrm{NO}_{x}$ or under the possible range of conditions in the ambient atmosphere. In the application of UNIPAR to the aromatic LLPS
SOA system, Im et al. (2014) found the $Y_{\text {SOA }}$ of toluene to be higher in the presence of ABS than AS at $30 \%$ RH but the same at $60 \% \mathrm{RH}$, meaning that the SOA formation of toluene is less sensitive to $\left[\mathrm{H}^{+}\right]$but more sensitive to LWC than isoprene. The relationship between $Y_{\mathrm{SOA}}, \mathrm{LWC}$ and $\left[\mathrm{H}^{+}\right]$will not only vary dynamically for different $\mathrm{VOC} / \mathrm{NO}_{x}$ but also between different VOC systems. Failure to account for these relationships in regional- and global-scale models may lead to significant underestimation of SOA formation in acidic and humid conditions.

\section{The Supplement related to this article is available online at doi:10.5194/acp-16-5993-2016-supplement.}

Acknowledgements. This work was supported by a grant from the National Science Foundation (ATM-0852747) and a grant from the National Research Foundation of Korea (2014M3C8A5032316).

Edited by: K. Tsigaridis

\section{References}

Aiken, A. C., DeCarlo, P. F., Kroll, J. H., Worsnop, D. R., Huffman, J. A., Docherty, K. S., Ulbrich, I. M., Mohr, C., Kimmel, J. R., Sueper, D., Sun, Y., Zhang, Q., Trimborn, A., Northway, M., Ziemann, P. J., Canagaratna, M. R., Onasch, T. B., Alfarra, M. R., Prevot, A. S. H., Dommen, J., Duplissy, J., Metzger, A., Baltensperger, U., and Jimenez, J. L.: O / C and OM / OC Ratios of Primary, Secondary, and Ambient Organic Aerosols with HighResolution Time-of-Flight Aerosol Mass Spectrometry, Environ. Sci. Technol., 42, 4478-4485, doi:10.1021/es703009q, 2008.

Bertram, A. K., Martin, S. T., Hanna, S. J., Smith, M. L., Bodsworth, A., Chen, Q., Kuwata, M., Liu, A., You, Y., and Zorn, S. R.: Predicting the relative humidities of liquid-liquid phase separation, efflorescence, and deliquescence of mixed particles of ammonium sulfate, organic material, and water using the organic-to-sulfate mass ratio of the particle and the oxygen-tocarbon elemental ratio of the organic component, Atmos. Chem. Phys., 11, 10995-11006, doi:10.5194/acp-11-10995-2011, 2011.

Budisulistiorini, S. H., Canagaratna, M. R., Croteau, P. L., Marth, W. J., Baumann, K., Edgerton, E. S., Shaw, S. L., Knipping, E. M., Worsnop, D. R., Jayne, J. T., Gold, A., and Surratt, J. D.: Real-Time Continuous Characterization of Secondary Organic Aerosol Derived from Isoprene Epoxydiols in Downtown Atlanta, Georgia, Using the Aerodyne Aerosol Chemical Speciation Monitor, Environ. Sci. Technol., 47, 5686-5694, doi:10.1021/es400023n, 2013.

Budisulistiorini, S. H., Li, X., Bairai, S. T., Renfro, J., Liu, Y., Liu, Y. J., McKinney, K. A., Martin, S. T., McNeill, V. F., Pye, H. O. T., Nenes, A., Neff, M. E., Stone, E. A., Mueller, S., Knote, C., Shaw, S. L., Zhang, Z., Gold, A., and Surratt, J. D.: Examining the effects of anthropogenic emissions on isoprenederived secondary organic aerosol formation during the 2013 
Southern Oxidant and Aerosol Study (SOAS) at the Look Rock, Tennessee ground site, Atmos. Chem. Phys., 15, 8871-8888, doi:10.5194/acp-15-8871-2015, 2015.

Carlton, A. G., Wiedinmyer, C., and Kroll, J. H.: A review of Secondary Organic Aerosol (SOA) formation from isoprene, Atmos. Chem. Phys., 9, 4987-5005, doi:10.5194/acp-9-4987-2009, 2009.

Chan, A. W. H., Chan, M. N., Surratt, J. D., Chhabra, P. S., Loza, C. L., Crounse, J. D., Yee, L. D., Flagan, R. C., Wennberg, P. O., and Seinfeld, J. H.: Role of aldehyde chemistry and $\mathrm{NO}_{x}$ concentrations in secondary organic aerosol formation, Atmos. Chem. Phys., 10, 7169-7188, doi:10.5194/acp-10-7169-2010, 2010.

Chan, M. N., Surratt, J. D., Claeys, M., Edgerton, E. S., Tanner, R. L., Shaw, S. L., Zheng, M., Knipping, E. M., Eddingsaas, N. C., Wennberg, P. O. and Seinfeld, J. H.: Characterization and Quantification of Isoprene-Derived Epoxydiols in Ambient Aerosol in the Southeastern United States, Environ. Sci. Technol., 44, 45904596, doi:10.1021/es100596b, 2010.

Chen, Q., Liu, Y., Donahue, N. M., Shilling, J. E., and Martin, S. T.: Particle-Phase Chemistry of Secondary Organic Material: Modeled Compared to Measured O : C and H:C Elemental Ratios Provide Constraints, Environ. Sci. Technol., 45, 4763-4770, doi:10.1021/es104398s, 2011.

Claeys, M., Wang, W., Ion, A. C., Kourtchev, I., Gelencsér, A., and Maenhaut, W.: Formation of secondary organic aerosols from isoprene and its gas-phase oxidation products through reaction with hydrogen peroxide, Atmos. Environ., 38, 4093-4098, doi:10.1016/j.atmosenv.2004.06.001, 2004.

Clegg, S. L., Brimblecombe, P., and Wexler, A. S.: Thermodynamic Model of the System $\mathrm{H}^{+}-\mathrm{NH}_{4}^{+}-\mathrm{SO}_{4}^{2-}-\mathrm{NO}_{3}^{-}-\mathrm{H}_{2} \mathrm{O}$ at Tropospheric Temperatures, J. Phys. Chem. A, 102, 2137-2154, doi:10.1021/jp973042r, 1998.

Darer, A. I., Cole-Filipiak, N. C., O'Connor, A. E., and Elrod, M. J.: Formation and Stability of Atmospherically Relevant IsopreneDerived Organosulfates and Organonitrates, Environ. Sci. Technol., 45, 1895-1902, doi:10.1021/es103797z, 2011.

Dommen, J., Metzger, A., Duplissy, J., Kalberer, M., Alfarra, M. R., Gascho, A., Weingartner, E., Prevot, A. S. H., Verheggen, B., and Baltensperger, U.: Laboratory observation of oligomers in the aerosol from isoprene/ $\mathrm{NO}_{x}$ photooxidation, Geophys. Res. Lett., 33, L13805, doi:10.1029/2006GL026523, 2006.

Eddingsaas, N. C., VanderVelde, D. G., and Wennberg, P. O.: Kinetics and Products of the Acid-Catalyzed Ring-Opening of Atmospherically Relevant Butyl Epoxy Alcohols, J. Phys. Chem. A, 114, 8106-8113, doi:10.1021/jp103907c, 2010.

Eddingsaas, N. C., Loza, C. L., Yee, L. D., Chan, M., Schilling, K. A., Chhabra, P. S., Seinfeld, J. H., and Wennberg, P. O.: $\alpha$-pinene photooxidation under controlled chemical conditions - Part 2: SOA yield and composition in low- and high- $\mathrm{NO}_{x}$ environments, Atmos. Chem. Phys., 12, 7413-7427, doi:10.5194/acp-12-74132012, 2012.

Edney, E. O., Kleindienst, T. E., Jaoui, M., Lewandowski, M., Offenberg, J. H., Wang, W., and Claeys, M.: Formation of 2methyl tetrols and 2-methylglyceric acid in secondary organic aerosol from laboratory irradiated isoprene/ $/ \mathrm{NO}_{X} / \mathrm{SO}_{2} /$ air mixtures and their detection in ambient $\mathrm{PM}_{2.5}$ samples collected in the eastern United States, Atmos. Environ., 39, 5281-5289, doi:10.1016/j.atmosenv.2005.05.031, 2005.
Finlayson-Pitts, B. J. and Pitts Jr., J. N.: Atmospheric Chemistry of Tropospheric Ozone Formation: Scientific and Regulatory Implications, J. Air Waste Ma., 43, 1091-1100, doi:10.1080/1073161X.1993.10467187, 1993.

Galloway, M. M., Chhabra, P. S., Chan, A. W. H., Surratt, J. D., Flagan, R. C., Seinfeld, J. H., and Keutsch, F. N.: Glyoxal uptake on ammonium sulphate seed aerosol: reaction products and reversibility of uptake under dark and irradiated conditions, Atmos. Chem. Phys., 9, 3331-3345, doi:10.5194/acp-9-3331-2009, 2009.

Gaston, C. J., Riedel, T. P., Zhang, Z., Gold, A., Surratt, J. D., and Thornton, J. A.: Reactive Uptake of an Isoprene-Derived Epoxydiol to Submicron Aerosol Particles, Environ. Sci. Technol., 48, 11178-11186, doi:10.1021/es5034266, 2014.

Guenther, A., Karl, T., Harley, P., Wiedinmyer, C., Palmer, P. I., and Geron, C.: Estimates of global terrestrial isoprene emissions using MEGAN (Model of Emissions of Gases and Aerosols from Nature), Atmos. Chem. Phys., 6, 3181-3210, doi:10.5194/acp-63181-2006, 2006

Guo, H., Xu, L., Bougiatioti, A., Cerully, K. M., Capps, S. L., Hite Jr., J. R., Carlton, A. G., Lee, S.-H., Bergin, M. H., Ng, N. L., Nenes, A., and Weber, R. J.: Fine-particle water and $\mathrm{pH}$ in the southeastern United States, Atmos. Chem. Phys., 15, 5211-5228, doi:10.5194/acp-15-5211-2015, 2015.

Heintzenberg, J.: Fine particles in the global troposphere A review, Tellus B, 41, 149-160, doi:10.1111/j.16000889.1989.tb00132.x, 1989.

Hennigan, C. J., Bergin, M. H., Dibb, J. E., and Weber, R. J.: Enhanced secondary organic aerosol formation due to water uptake by fine particles, Geophys. Res. Lett., 35, L18801, doi:10.1029/2008GL035046, 2008.

Henze, D. K. and Seinfeld, J. H.: Global secondary organic aerosol from isoprene oxidation, Geophys. Res. Lett., 33, L09812, doi:10.1029/2006GL025976, 2006.

Hodas, N., Zuend, A., Mui, W., Flagan, R. C., and Seinfeld, J. H.: Influence of particle-phase state on the hygroscopic behavior of mixed organic-inorganic aerosols, Atmos. Chem. Phys., 15, 5027-5045, doi:10.5194/acp-15-5027-2015, 2015.

Im, Y., Jang, M., and Beardsley, R. L.: Simulation of aromatic SOA formation using the lumping model integrated with explicit gas-phase kinetic mechanisms and aerosol-phase reactions, Atmos. Chem. Phys., 14, 4013-4027, doi:10.5194/acp-14-40132014, 2014.

Ip, H. S. S., Huang, X. H. H., and Yu, J. Z.: Effective Henry's law constants of glyoxal, glyoxylic acid, and glycolic acid, Geophys. Res. Lett., 36, L01802, doi:10.1029/2008GL036212, 2009.

Jang, M. and Kamens, R. M.: A Thermodynamic Approach for Modeling Partitioning of Semivolatile Organic Compounds on Atmospheric Particulate Matter: Humidity Effects, Environ. Sci. Technol., 32, 1237-1243, doi:10.1021/es970773w, 1998.

Jang, M. and Kamens, R. M.: Characterization of Secondary Aerosol from the Photooxidation of Toluene in the Presence of NOx and 1-Propene, Environ. Sci. Technol., 35, 3626-3639, doi:10.1021/es010676+, 2001.

Jang, M., Czoschke, N. M., Lee, S., and Kamens, R. M.: Heterogeneous Atmospheric Aerosol Production by AcidCatalyzed Particle-Phase Reactions, Science, 298, 814-817, doi:10.1126/science.1075798, 2002. 
Jang, M., Carroll, B., Chandramouli, B., and Kamens, R. M.: Particle Growth by Acid-Catalyzed Heterogeneous Reactions of Organic Carbonyls on Preexisting Aerosols, Environ. Sci. Technol., 37, 3828-3837, doi:10.1021/es021005u, 2003.

Jang, M., Czoschke, N. M., and Northcross, A. L.: Semiempirical Model for Organic Aerosol Growth by Acid-Catalyzed Heterogeneous Reactions of Organic Carbonyls, Environ. Sci. Technol., 39, 164-174, doi:10.1021/es048977h, 2005.

Jang, M., Czoschke, N. M., Northcross, A. L., Cao, G., and Shaof, D.: SOA Formation from Partitioning and Heterogeneous Reactions: Model Study in the Presence of Inorganic Species, Environ. Sci. Technol., 40, 3013-3022, doi:10.1021/es0511220, 2006.

Jang, M., Cao, G., and Paul, J.: Colorimetric Particle Acidity Analysis of Secondary Organic Aerosol Coating on Submicron Acidic Aerosols, Aerosol Sci. Tech., 42, 409-420, doi:10.1080/02786820802154861, 2008.

Jeffries, H. E., Gary, M. W., Kessler, M., and Sexton, K. G.: Morphecule reaction mechanism, MORPHO, ALLOMORPHIC simulation software, 1998.

Joback, K. G. and Reid, R. C.: Estimation of Pure-Component Properties from Group-Contributions, Chem. Eng. Commun., 57, 233-243, doi:10.1080/00986448708960487, 1987.

Kleindienst, T. E., Jaoui, M., Lewandowski, M., Offenberg, J. H., Lewis, C. W., Bhave, P. V., and Edney, E. O.: Estimates of the contributions of biogenic and anthropogenic hydrocarbons to secondary organic aerosol at a southeastern US location, Atmos. Environ., 41, 8288-8300, doi:10.1016/j.atmosenv.2007.06.045, 2007.

Kolská, Z., Růžička, V., and Gani, R.: Estimation of the Enthalpy of Vaporization and the Entropy of Vaporization for Pure Organic Compounds at $298.15 \mathrm{~K}$ and at Normal Boiling Temperature by a Group Contribution Method, Ind. Eng. Chem. Res., 44, 84368454, doi:10.1021/ie050113x, 2005.

Kroll, J. H., Ng, N. L., Murphy, S. M., Flagan, R. C., and Seinfeld, J. H.: Secondary organic aerosol formation from isoprene photooxidation under high- $\mathrm{NO}_{x}$ conditions, Geophys. Res. Lett., 32, L18808, doi:10.1029/2005GL023637, 2005.

Kroll, J. H., Ng, N. L., Murphy, S. M., Flagan, R. C., and Seinfeld, J. H.: Secondary Organic Aerosol Formation from Isoprene Photooxidation, Environ. Sci. Technol., 40, 1869-1877, doi:10.1021/es0524301, 2006.

Kuwata, M., Shao, W., Lebouteiller, R., and Martin, S. T.: Classifying organic materials by oxygen-to-carbon elemental ratio to predict the activation regime of Cloud Condensation Nuclei (CCN), Atmos. Chem. Phys., 13, 5309-5324, doi:10.5194/acp-13-53092013, 2013.

Kuwata, M., Liu, Y., McKinney, K., and Martin, S. T.: Physical state and acidity of inorganic sulfate can regulate the production of secondary organic material from isoprene photooxidation products, Phys. Chem. Chem. Phys., 17, 5670-5678, doi:10.1039/C4CP04942J, 2015.

Li, J. and Jang, M.: Aerosol Acidity Measurement Using Colorimetry Coupled With a Reflectance UVVisible Spectrometer, Aerosol Sci. Tech., 46, 833-842, doi:10.1080/02786826.2012.669873, 2012.

Li, J., Jang, M., and Beardsley, R. L.: Dialkylsulfate formation in sulfuric acid-seeded secondary organic aerosol produced us- ing an outdoor chamber under natural sunlight, Environ. Chem., doi:10.1071/EN15129, online first, 2015.

Liao, J., Froyd, K. D., Murphy, D. M., Keutsch, F. N., Yu, G., Wennberg, P. O., St. Clair, J. M., Crounse, J. D., Wisthaler, A., Mikoviny, T., Jimenez, J. L., Campuzano-Jost, P., Day, D. A., Hu, W., Ryerson, T. B., Pollack, I. B., Peischl, J., Anderson, B. E., Ziemba, L. D., Blake, D. R., Meinardi, S. and Diskin, G.: Airborne measurements of organosulfates over the continental U.S., J. Geophys. Res.-Atmos., 120, 2990-3005, doi:10.1002/2014JD022378, 2015.

Liggio, J., Li, S.-M., and McLaren, R.: Heterogeneous Reactions of Glyoxal on Particulate Matter: Identification of Acetals and Sulfate Esters, Environ. Sci. Technol., 39, 1532-1541, doi:10.1021/es048375y, 2005.

Lim, Y. B., Tan, Y., Perri, M. J., Seitzinger, S. P., and Turpin, B. J.: Aqueous chemistry and its role in secondary organic aerosol (SOA) formation, Atmos. Chem. Phys., 10, 1052110539, doi:10.5194/acp-10-10521-2010, 2010.

Limbeck, A., Kulmala, M., and Puxbaum, H.: Secondary organic aerosol formation in the atmosphere via heterogeneous reaction of gaseous isoprene on acidic particles, Geophys. Res. Lett., 30, 1996, doi:10.1029/2003GL017738, 2003.

Lin, Y.-H., Zhang, Z., Docherty, K. S., Zhang, H., Budisulistiorini, S. H., Rubitschun, C. L., Shaw, S. L., Knipping, E. M., Edgerton, E. S., Kleindienst, T. E., Gold, A., and Surratt, J. D.: Isoprene Epoxydiols as Precursors to Secondary Organic Aerosol Formation: Acid-Catalyzed Reactive Uptake Studies with Authentic Compounds, Environ. Sci. Technol., 46, 250258, doi:10.1021/es202554c, 2012.

Marais, E. A., Jacob, D. J., Jimenez, J. L., Campuzano-Jost, P., Day, D. A., Hu, W., Krechmer, J., Zhu, L., Kim, P. S., Miller, C. C., Fisher, J. A., Travis, K., Yu, K., Hanisco, T. F., Wolfe, G. M., Arkinson, H. L., Pye, H. O. T., Froyd, K. D., Liao, J., and McNeill, V. F.: Aqueous-phase mechanism for secondary organic aerosol formation from isoprene: application to the southeast United States and co-benefit of $\mathrm{SO}_{2}$ emission controls, Atmos. Chem. Phys., 16, 1603-1618, doi:10.5194/acp-16-16032016, 2016.

Matsunaga, A. and Ziemann, P. J.: Gas-Wall Partitioning of Organic Compounds in a Teflon Film Chamber and Potential Effects on Reaction Product and Aerosol Yield Measurements, Aerosol Sci. Tech., 44, 881-892, doi:10.1080/02786826.2010.501044, 2010.

McNeill, V. F., Woo, J. L., Kim, D. D., Schwier, A. N., Wannell, N. J., Sumner, A. J., and Barakat, J. M.: Aqueous-Phase Secondary Organic Aerosol and Organosulfate Formation in Atmospheric Aerosols: A Modeling Study, Environ. Sci. Technol., 46, 80758081, doi:10.1021/es3002986, 2012.

Minerath, E. C., Casale, M. T., and Elrod, M. J.: Kinetics Feasibility Study of Alcohol Sulfate Esterification Reactions in Tropospheric Aerosols, Environ. Sci. Technol., 42, 4410-4415, doi:10.1021/es8004333, 2008.

Murphy, D. M., Cziczo, D. J., Froyd, K. D., Hudson, P. K., Matthew, B. M., Middlebrook, A. M., Peltier, R. E., Sullivan, A., Thomson, D. S., and Weber, R. J.: Single-particle mass spectrometry of tropospheric aerosol particles, J. Geophys. Res.-Atmos., 111, D23S32, doi:10.1029/2006JD007340, 2006.

Ng, N. L., Kwan, A. J., Surratt, J. D., Chan, A. W. H., Chhabra, P. S., Sorooshian, A., Pye, H. O. T., Crounse, J. D., Wennberg, P. O., Flagan, R. C., and Seinfeld, J. H.: Secondary organic aerosol 
(SOA) formation from reaction of isoprene with nitrate radicals $\left(\mathrm{NO}_{3}\right)$, Atmos. Chem. Phys., 8, 4117-4140, doi:10.5194/acp-84117-2008, 2008.

Nguyen, T. B., Bateman, A. P., Bones, D. L., Nizkorodov, S. A., Laskin, J. and Laskin, A.: High-resolution mass spectrometry analysis of secondary organic aerosol generated by ozonolysis of isoprene, Atmos. Environ., 44, 1032-1042, doi:10.1016/j.atmosenv.2009.12.019, 2010.

Nguyen, T. B., Roach, P. J., Laskin, J., Laskin, A., and Nizkorodov, S. A.: Effect of humidity on the composition of isoprene photooxidation secondary organic aerosol, Atmos. Chem. Phys., 11, 6931-6944, doi:10.5194/acp-11-6931-2011, 2011.

Nozière, B., Ekström, S., Alsberg, T., and Holmström, S.: Radical-initiated formation of organosulfates and surfactants in atmospheric aerosols, Geophys. Res. Lett., 37, L05806, doi:10.1029/2009GL041683, 2010.

Odum, J. R., Hoffman, T., Bowman, F., Collins, D., Flagan, R. C., and Seinfeld, J. H.: Gas/Particle Partitioning and Secondary Organic Aerosol Yields, Environ. Sci. Technol., 30, 2580-2585, 1996.

Pandis, S. N., Paulson, S. E., Seinfeld, J. H., and Flagan, R. C.: Aerosol formation in the photooxidation of isoprene and $\beta$-pinene, Atmos. Environ. A-Gen., 25, 997-1008, doi:10.1016/0960-1686(91)90141-S, 1991.

Pankow, J. F.: An absorption model of gas/particle partitioning of organic compounds in the atmosphere, Atmos. Environ., 28, 185-188, doi:10.1016/1352-2310(94)90093-0, 1994.

Paulot, F., Crounse, J. D., Kjaergaard, H. G., Kürten, A., Clair, J. M. S., Seinfeld, J. H., and Wennberg, P. O.: Unexpected Epoxide Formation in the Gas-Phase Photooxidation of Isoprene, Science, 325, 730-733, doi:10.1126/science.1172910, 2009.

Pinho, P. G., Pio, C. A., and Jenkin, M. E.: Evaluation of isoprene degradation in the detailed tropospheric chemical mechanism, MCM v3, using environmental chamber data, Atmos. Environ., 39, 1303-1322, doi:10.1016/j.atmosenv.2004.11.014, 2005.

Pye, H. O. T., Pinder, R. W., Piletic, I. R., Xie, Y., Capps, S. L., Lin, Y.-H., Surratt, J. D., Zhang, Z., Gold, A., Luecken, D. J., Hutzell, W. T., Jaoui, M., Offenberg, J. H., Kleindienst, T. E., Lewandowski, M., and Edney, E. O.: Epoxide Pathways Improve Model Predictions of Isoprene Markers and Reveal Key Role of Acidity in Aerosol Formation, Environ. Sci. Technol., 47, 11056-11064, doi:10.1021/es402106h, 2013.

Kamens, R. M., Gery, M. W., Jeffries, H. E., Jackson, M., and Cole, E. I.: Ozone-isoprene reactions: Product formation and aerosol potential, Int. J. Chem. Kinet., 14, 955-975, doi:10.1002/kin.550140902, 1982.

Rollins, A. W., Browne, E. C., Min, K.-E., Pusede, S. E., Wooldridge, P. J., Gentner, D. R., Goldstein, A. H., Liu, S., Day, D. A., Russell, L. M., and Cohen, R. C.: Evidence for $\mathrm{NO}_{x}$ Control over Nighttime SOA Formation, Science, 337, 1210-1212, doi:10.1126/science.1221520, 2012.

Saunders, S. M., Jenkin, M. E., Derwent, R. G., and Pilling, M. J.: World wide web site of a master chemical mechanism (MCM) for use in tropospheric chemistry models, Atmos. Environ., 31, 1249-1249, doi:10.1016/S1352-2310(97)85197-7, 1997.

Saunders, S. M., Jenkin, M. E., Derwent, R. G., and Pilling, M. J.: Protocol for the development of the Master Chemical Mechanism, MCM v3 (Part A): tropospheric degradation of non- aromatic volatile organic compounds, Atmos. Chem. Phys., 3, 161-180, doi:10.5194/acp-3-161-2003, 2003.

Schell, B., Ackermann, I. J., Hass, H., Binkowski, F. S., and Ebel, A.: Modeling the formation of secondary organic aerosol within a comprehensive air quality model system, J. Geophys. Res.Atmos., 106, 28275-28293, doi:10.1029/2001JD000384, 2001.

Song, M., Liu, P. F., Hanna, S. J., Li, Y. J., Martin, S. T., and Bertram, A. K.: Relative humidity-dependent viscosities of isoprene-derived secondary organic material and atmospheric implications for isoprene-dominant forests, Atmos. Chem. Phys., 15, 5145-5159, doi:10.5194/acp-15-5145-2015, 2015.

Stein, S. E. and Brown, R. L.: Estimation of normal boiling points from group contributions, J. Chem. Inf. Model., 34, 581-587, doi:10.1021/ci00019a016, 1994.

Surratt, J. D., Murphy, S. M., Kroll, J. H., Ng, N. L., Hildebrandt, L., Sorooshian, A., Szmigielski, R., Vermeylen, R., Maenhaut, W., Claeys, M., Flagan, R. C., and Seinfeld, J. H.: Chemical composition of secondary organic aerosol formed from the photooxidation of isoprene, J. Phys. Chem. A, 110, 9665-9690, doi:10.1021/jp061734m, 2006.

Surratt, J. D., Lewandowski, M., Offenberg, J. H., Jaoui, M., Kleindienst, T. E., Edney, E. O., and Seinfeld, J. H.: Effect of Acidity on Secondary Organic Aerosol Formation from Isoprene, Environ. Sci. Technol., 41, 5363-5369, doi:10.1021/es0704176, 2007.

Surratt, J. D., Chan, A. W. H., Eddingsaas, N. C., Chan, M., Loza, C. L., Kwan, A. J., Hersey, S. P., Flagan, R. C., Wennberg, P. O., and Seinfeld, J. H.: Reactive intermediates revealed in secondary organic aerosol formation from isoprene, P. Natl. Acad. Sci. USA, 107, 6640-6645, doi:10.1073/pnas.0911114107, 2010.

Virtanen, A., Joutsensaari, J., Koop, T., Kannosto, J., Yli-Pirilä, P., Leskinen, J., Mäkelä, J. M., Holopainen, J. K., Pöschl, U., Kulmala, M., Worsnop, D. R., and Laaksonen, A.: An amorphous solid state of biogenic secondary organic aerosol particles, Nature, 467, 824-827, doi:10.1038/nature09455, 2010.

Volkamer, R., San Martini, F., Molina, L. T., Salcedo, D., Jimenez, J. L., and Molina, M. J.: A missing sink for gas-phase glyoxal in Mexico City: Formation of secondary organic aerosol, Geophys. Res. Lett., 34, L19807, doi:10.1029/2007GL030752, 2007.

Waxman, E. M., Elm, J., Kurtén, T., Mikkelsen, K. V., Ziemann, P. J., and Volkamer, R.: Glyoxal and Methylglyoxal Setschenow Salting Constants in Sulfate, Nitrate, and Chloride Solutions: Measurements and Gibbs Energies, Environ. Sci. Technol., 49, 11500-11508, doi:10.1021/acs.est.5b02782, 2015.

Wiedinmyer, C., Friedfeld, S., Baugh, W., Greenberg, J., Guenther, A., Fraser, M., and Allen, D.: Measurement and analysis of atmospheric concentrations of isoprene and its reaction products in central Texas, Atmos. Environ., 35, 1001-1013, doi:10.1016/S1352-2310(00)00406-4, 2001.

Woo, J. L. and McNeill, V. F.: simpleGAMMA v1.0 - a reduced model of secondary organic aerosol formation in the aqueous aerosol phase (aaSOA), Geosci. Model Dev., 8, 1821-1829, doi:10.5194/gmd-8-1821-2015, 2015.

Xu, L., Kollman, M. S., Song, C., Shilling, J. E., and Ng, N. L.: Effects of $\mathrm{NO}_{x}$ on the Volatility of Secondary Organic Aerosol from Isoprene Photooxidation, Environ. Sci. Technol., 48, 2253 2262, doi:10.1021/es404842g, 2014.

Xu, L., Guo, H., Boyd, C. M., Klein, M., Bougiatioti, A., Cerully, K. M., Hite, J. R., Isaacman-VanWertz, G., Kreisberg, N. M., 
Knote, C., Olson, K., Koss, A., Goldstein, A. H., Hering, S. V., Gouw, J. de, Baumann, K., Lee, S.-H., Nenes, A., Weber, R. J., and Ng, N. L.: Effects of anthropogenic emissions on aerosol formation from isoprene and monoterpenes in the southeastern United States, P. Natl. Acad. Sci. USA, 112, 37-42, doi:10.1073/pnas.1417609112, 2015.

Zhang, H., Worton, D. R., Lewandowski, M., Ortega, J., Rubitschun, C. L., Park, J.-H., Kristensen, K., Campuzano-Jost, P., Day, D. A., Jimenez, J. L., Jaoui, M., Offenberg, J. H., Kleindienst, T. E., Gilman, J., Kuster, W. C., de Gouw, J., Park, C., Schade, G. W., Frossard, A. A., Russell, L., Kaser, L., Jud, W., Hansel, A., Cappellin, L., Karl, T., Glasius, M., Guenther, A., Goldstein, A. H., Seinfeld, J. H., Gold, A., Kamens, R. M., and Surratt, J. D.: Organosulfates as Tracers for Secondary Organic Aerosol (SOA) Formation from 2-Methyl-3-Buten-2-ol (MBO) in the Atmosphere, Environ. Sci. Technol., 46, 94379446, doi:10.1021/es301648z, 2012.
Zhang, X., Cappa, C. D., Jathar, S. H., McVay, R. C., Ensberg, J. J., Kleeman, M. J., and Seinfeld, J. H.: Influence of vapor wall loss in laboratory chambers on yields of secondary organic aerosol, P. Natl. Acad. Sci. USA, 111, 5802-5807, doi:10.1073/pnas.1404727111, 2014.

Zhang, X., McVay, R. C., Huang, D. D., Dalleska, N. F., Aumont, B., Flagan, R. C., and Seinfeld, J. H.: Formation and evolution of molecular products in $\alpha$-pinene secondary organic aerosol, P. Natl. Acad. Sci. USA, 112, 14168-14173, doi:10.1073/pnas.1517742112, 2015.

Zhang, Y., Seigneur, C., Seinfeld, J. H., Jacobson, M., Clegg, S. L., and Binkowski, F. S.: A comparative review of inorganic aerosol thermodynamic equilibrium modules: similarities, differences, and their likely causes, Atmos. Environ., 34, 117-137, doi:10.1016/S1352-2310(99)00236-8, 2000.

Zhao, L., Li, P., and Yalkowsky, S. H.: Predicting the Entropy of Boiling for Organic Compounds, J. Chem. Inf. Model., 39, 11121116, doi:10.1021/ci990054w, 1999. 